
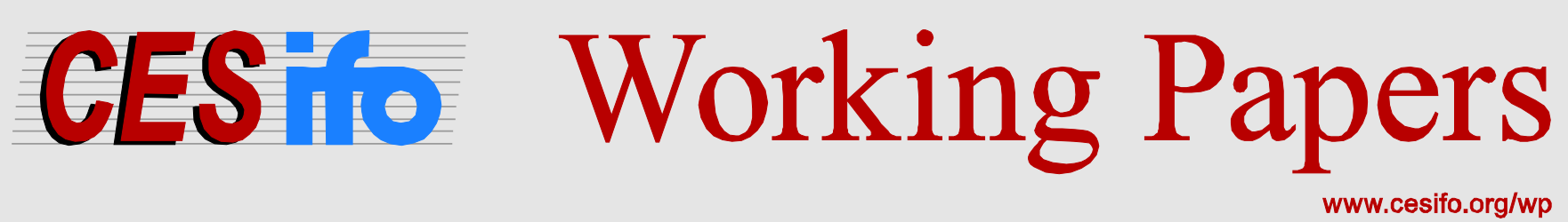

\title{
Effects of Fiscal Rules 85 Years` Experience in Switzerland
}

\author{
Heiko T. Burret \\ Lars P. Feld
}

CESIFO WORKING PAPER NO. 6063

CATEgORY 1: PUBlic FinANCE

August 2016

An electronic version of the paper may be downloaded

- from the SSRN website:

- from the RePEc website:

- from the CESifo website:

wWw.SSRN.com

Www.RePEc.org

www.CESifo-group.org/wp 


\title{
Effects of Fiscal Rules 85 Years' Experience in Switzerland
}

\begin{abstract}
The paper investigates the fiscal effects of Swiss cantonal debt brakes by taking explicitly into account the rules' coverage. An in-depth analysis provides unique evidence that suggests the following: First, fiscal rules at the cantonal level have a negative effect on public deficits, which is stronger the better the analyzed budget position corresponds with the variable targeted by the rules. Second, cantonal debt brakes are rather not associated with substantial evasive measures. Third, cantonal fiscal rules tend to mitigate political budget cycles and shock-related deficits.
\end{abstract}

JEL-Codes: H720, H740, H770, D720, K390.

Keywords: Switzerland, fiscal rule, debt brake, budget cycle, election, fiscal shock.

Heiko T. Burret

Walter Eucken Institute

Goethestr. 10

Germany - 79100 Freiburg

burret@eucken.de
Lars P. Feld*

University of Freiburg

Walter Eucken Institute

Goethestr. 10

Germany - 79100 Freiburg

feld@eucken.de

*corresponding author

\section{August 2016}

We would like to thank Emma Karslake, Lisa Lauton and Johanna Schworm for valuable research assistance and Christoph Schaltegger for providing us with cantonal data on realized and forecasted revenue and expenditure. We are grateful to Martina Neuhaus from the Swiss Federal Department of Finance for providing us with the best data available and to various public sector entities for providing us with legal texts on fiscal rules. 


\section{Introduction}

It is widely acknowledged that democratically elected governments have a tendency to run budget deficits and incur debt. A prominent solution to constrain fiscal policy and alleviate excessive deficits is the introduction of fiscal rules. Such constraints have a long tradition in Switzerland. Over 85 years ago, on $17^{\text {th }}$ June 1929, the canton of St. Gall implemented what is today often referred to as the first debt brake. While fiscal constraints were not new in 1929, St. Gall's regulation has been particularly strong and credible as it entails innovative elements such as a correction mechanism ever since. ${ }^{1}$

However, the intended effect of fiscal rules, i.e., disciplining policy-makers, might be undermined as politicians often find ingenious ways of retaining fiscal discretion while satisfying fiscal rules at the same time. In the end, fiscal rules might constrain the targeted variable perfectly, while no substantial improvement of the overall fiscal position takes place. It thus seems essential to differentiate between the direct effect of fiscal rules on the targeted variable and the consequential (unintended) indirect effects, e.g. evasive reactions, which could counter the initial effect.

In addition, the impact of fiscal rules might vary with the circumstances in the restricted entity. In times of political stability and buoyant revenue, fiscal constraints should only play a minor role. If a jurisdiction is, however, hit by a fiscal shock, then the fiscal rules might take their full effect and mitigate a shock-related deterioration of public finances. Similarly, the impact of fiscal rules should be particularly notable in election years as incumbents are generally tempted to conduct an expansionary fiscal policy in order to win the upcoming election.

The paper addresses these issues raised by exploiting a rich dataset that covers the 26 Swiss cantons (states) during the years 1980-2011. As most cantons have introduced a debt brake by now, Switzerland provides a natural laboratory to empirically test the impact of fiscal rules. The paper stands out from previous studies as we are among the first to investigate the effect of fiscal rules on various budget components, evasive measures, political budget cycles and on the responsiveness of cantonal budgets to fiscal shocks. A difference-in-differences approach shows that the deficit-constraining impact of fiscal rules at the cantonal level is stronger the more narrowly defined the analyzed budget variable is - i.e., the better the analyzed budget

\footnotetext{
${ }^{1}$ By comparison, lax fiscal rules can be found already in the $19^{\text {th }}$ century in, e.g., the Kingdom of Bavaria, the German Empire and in some US states and other Swiss cantons.
} 
position corresponds with the variable targeted by the rule. Despite the deficient coverage of most cantonal fiscal rules, we find little evidence that debt brakes are associated with a shift of expenditure from the (constrained) current budget to the (unconstrained) investment budget. An evasion into funds and special financing is rejected, too. Still, the results emphasize the importance of implementing fiscal rules that legally cover all accounts. Moreover, we provide unique evidence that cantonal debt brakes, which are particularly effective in election years and times of crisis, mitigate political budget cycles and shock-related deficits.

The remainder of the paper is organized as follows: Section 2 reviews the empirical literature; Section 3 briefly describes the cantonal fiscal framework; Section 4 presents the empirical strategy and model; Section 5 shows the baseline results; Section 6 discusses the robustness tests and Section 7 concludes.

\section{Literature Review}

A large range of literature on fiscal rules has emerged subsequent to Proposition 13 that limits property taxation in California. Despite the myriad of studies, Alesina and Passalacqua (2015) recently called for "more econometric work to quantify the benefits of balanced budget rules." We thus investigate the effects of fiscal rules on different budget components, political budget cycles and the responsiveness of cantonal budgets to fiscal shocks. Thereby the paper is broadly related to four areas of research:

A first strand of literature scrutinizes the effects of fiscal rules on public finances. Mitchell (1967) and Pogue (1970) were among the first to study the impact of fiscal constraints on US state finances. Most subsequent studies on the US suggest that strong budget rules support fiscal discipline - though the effect depends on the type and design of the rule. Similar evidence is

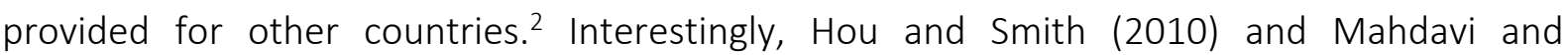
Westerlund (2011) find that the impact of fiscal rules in US states is more pronounced the more

\footnotetext{
${ }^{2}$ For the US, the literature has recently been surveyed by Burret and Feld (2014a). For Canada refer to Imbeau and Tellier (2004) and Tapp (2013), for Latin America to Alesina et al. (1999), for African countries to Gollwitzer (2010), for OECD countries to Guichard et al. (2007), for EU countries to De Haan et al. (1999), Ayuso-i-Casals et al. (2007), Hallerberg et al. (2007), Debrun et al. (2008), Grembi et al. (2012), Marneffe et al. (2011) and Foremny (2014) and for various economies to Singh and Plekhanov (2006), Lavigne (2011) and Blume and Voigt (2013). A recent meta-analysis confirms a constraining impact of fiscal rules (Heinemann et al., 2016). Related studies examine the effects of fiscal constraints on official budget forecasts (e.g., Frankel, 2011; Beetsma et al., 2009; Pina and Venes, 2011; Holm-Handulla et al., 2012; Frankel and Schreger, 2013). Similar to fiscal rules, a vast array of studies show that direct democratic institutions support fiscal discipline. For evidence on the US refer to, e.g., Matsusaka (1995) and on Switzerland refer to, e.g., Feld and Kirchgässner (2001a, b), Feld and Matsusaka (2003), Feld et al. (2008), Funk and Gathmann (2011) and Galletta and Jametti (2015).
} 
narrowly defined the underlying budget balance variable is. With respect to Switzerland several studies provide conclusive evidence that cantonal budget rules, i.e. debt brakes, are associated with lower deficits, while their impact on expenditure and revenue is ambiguous. However, the existing studies on Switzerland do not differentiate between direct effects (on the targeted budget components) and indirect effects (on the non-restricted budget components) of fiscal rules. Moreover, most papers analyze insufficient datasets with few fiscal rules, ignore the rules' (deficient) coverage or neglect fixed effects and issues of cross-sectional correlated standard errors (Table 1).

Table 1 Empirical Studies on the Effect of Swiss Cantonal Debt Brakes on Public Finances

\begin{tabular}{|c|c|c|c|c|c|c|c|}
\hline & Period & Rules & Coverage & Budget account & $\mathrm{FE}$ & SE & Findings: Cantonal debt brakes... \\
\hline $\begin{array}{l}\text { Feld/Kirchgässner } \\
\text { (2001a) }\end{array}$ & $\begin{array}{l}1986- \\
1997\end{array}$ & 4 & No & Total budget & & & $\begin{array}{l}\text {...reduce cantonal deficit and debt. } \\
\text {...show no effect on cantonal expenditure or revenue. }\end{array}$ \\
\hline $\begin{array}{l}\text { Schaltegger } \\
(2002)\end{array}$ & $\begin{array}{l}1980- \\
1998\end{array}$ & 5 & No & Total budget & & & $\begin{array}{l}\text {...reduce cantonal deficit and debt. } \\
\text {...show no effect on cantonal expenditure or revenue. }\end{array}$ \\
\hline $\begin{array}{l}\text { Feld/Kirchgässner } \\
\text { (2004) }\end{array}$ & $\begin{array}{l}1980- \\
1998\end{array}$ & 5 & No & Total budget & & & $\begin{array}{c}\text {...reduce cantonal and local deficit. } \\
\text {...show no effect on cantonal and } \\
\text { local expenditure or revenue. }\end{array}$ \\
\hline $\begin{array}{l}\text { Krogstrup/Wälti } \\
\text { (2008) }\end{array}$ & $\begin{array}{l}1955- \\
1999\end{array}$ & 5 & No & Total budget & 1) & & ...reduce cantonal deficit. \\
\hline $\begin{array}{l}\text { Feld/Kirchgässner } \\
\text { (2008) }\end{array}$ & $\begin{array}{l}1980- \\
1998\end{array}$ & 5 & No & Total budget & & & $\begin{array}{l}\text {...reduce cantonal and local deficit. } \\
\text {...show no effect on cantonal debt. }\end{array}$ \\
\hline $\begin{array}{l}\text { Schaltegger/Feld } \\
\text { (2009a) }\end{array}$ & $\begin{array}{l}1980- \\
1998\end{array}$ & 5 & No & Total budget & 1) & $\checkmark$ & $\begin{array}{r}\text {...show no clear-cut effect on cantonal } \\
\text { expenditure or revenue. }\end{array}$ \\
\hline $\begin{array}{l}\text { Feld et al. } \\
\text { (2010) }\end{array}$ & $\begin{array}{l}1980- \\
1998\end{array}$ & 5 & No & Total budget & 1) & $\checkmark$ & $\begin{array}{r}\text {...show no clear-cut effect on cantonal and } \\
\text { local expenditure or revenue. }\end{array}$ \\
\hline $\begin{array}{l}\text { Luechinger/ } \\
\text { Schaltegger (2013) }\end{array}$ & $\begin{array}{l}1984- \\
2005\end{array}$ & 13 & No & Total budget & $\checkmark$ & $\checkmark$ & $\begin{array}{r}. . . \text { reduce cantonal deficit and deficit projection. } \\
\ldots \text {...ncrease accuracy of budget forecasts. }\end{array}$ \\
\hline $\begin{array}{l}\text { Yerly } \\
\text { (2013) }\end{array}$ & $\begin{array}{l}1987- \\
2011\end{array}$ & 25 & No & $\begin{array}{l}\text { Total and } \\
\text { current budget }\end{array}$ & $\checkmark$ & & $\begin{array}{r}\text {...reduce cantonal total deficit. } \\
\text {...show no effect on cantonal current deficit. } \\
\text {...show no clear-cut effect on cantonal expenditure. }\end{array}$ \\
\hline $\begin{array}{l}\text { Burret/Feld } \\
(2014 b)\end{array}$ & $\begin{array}{l}1980- \\
2011\end{array}$ & 17 & No & Total budget & $\checkmark$ & $\checkmark$ & ...show no effect on local finances. \\
\hline
\end{tabular}

A second area of research analyses the relation between fiscal rules and evasive reactions. As fiscal gimmicks are hard to measure, empirical studies focus primarily on stock-flow adjustments in the EU or on unrestricted budget instruments in the US. Evidence for these countries largely suggests that politicians use various guises of fiscal gimmickry to evade fiscal rules. $^{3}$ The Swiss case has hardly been studied so far in this respect. This is surprising as

\footnotetext{
${ }^{3}$ For the US refer to, e.g., Mitchell (1967), von Hagen (1991, 1992), Bunch (1991), Strauch (1999), Chaney et al. (2002) and Costello et al. (2014) and for EU member countries to, e.g., Koen and van den Noord (2005), von Hagen and Wolff (2006), Milesi-Ferretti and Moriyama (2006) and Buti et al. (2007).
} 
Luechinger and Schaltegger (2013) explicitly mention that their finding that fiscal rules improve deficits could, at least partly, be due to creative accounting operations.

Similar to creative accounting, a vertical shifting of financing responsibilities to other levels of government can be seen as hidden device to circumvent fiscal rules and regain fiscal discretion. While evidence on that matter is mixed for the US (e.g., Nice, 1991; von Hagen, 1992; Kiewiet and Szakaly, 1996), Feld and Kirchgässner (2008) and Burret and Feld (2014b) suggest that Swiss cantonal budget constraints do not burden local finances. If anything, the cantonal rules support sound finances at the municipal level of government.

A third line of research focuses on the interaction between fiscal rules and political budget cycles. While literature frequently suggests that governments cut taxes and increase spending in order to win upcoming elections, evidence for Swiss cantons tends to reject such a political budget cycle. ${ }^{4}$ As the theory of political budget cycles is based on the politicians' ability to run deficits, fiscal rules are likely to mitigate these cycles. Such an effect is found for US states and low income countries (e.g., Rose, 2006; Alt and Rose, 2007; Ebeke and Ölçer; 2013). Similarly, Benito et al. (2013) conclude that in pre-election years, fiscal rules in Spanish municipalities create room for budgetary maneuvers in election years. While the loosely defined EU Stability and Growth Pact has, for obvious reasons, no effect on the magnitude of political budget cycles (Buti and Van den Noord, 2004), the Pact exacerbates electoral cycles in accounting gimmicks (Alt et al., 2014). Although Switzerland has a long tradition of fiscal rules, the relation between cantonal debt brakes and political budget cycles has, to the best of our knowledge, not been studied so far.

A fourth branch of literature examines the relation between fiscal rules and budgetary responses to cyclical fluctuations and fiscal shocks. As fiscal rules commonly restrict politicians' ability to run deficits, the constraints might induce harsh budgetary adjustments in case of negative fiscal shocks and impair counter-cyclical fiscal policy in downturns. While evidence for the US largely suggests that strict balanced budget requirements lower the cyclical responsiveness of state budgets, the rules' effect on business cycle volatility is ambiguous (e.g., Eichengreen and Bayoumi, 1994; Bayoumi and Eichengreen, 1995; Alesina and Bayoumi, 1996; Levinson, 1998, 2007; Sørensen et al., 2001; Fatás and Mihov, 2006; Primo, 2006; Krol and

\footnotetext{
${ }^{4}$ The theory of political business cycles can be traced back to Nordhaus (1975). A survey of empirical literature is provided by, e.g., Drazen (2000) and Klomp and de Haan (2013). For evidence on Switzerland refer to, e.g., Pétry (2004), Martin and Soguel (2004) and Krishnakumar et al. (2010).
} 
Svorny, 2007). Along the same lines, Poterba (1994) and Alt and Lowry (1994) find sharper budgetary reactions to unexpected deficit shocks in US states with fiscal constraints. We are not aware of any study that analyzes the question for Switzerland.

\section{Cantonal Fiscal Framework}

The Swiss federation is made up of three layers of governments, i.e., the federal level, the 26 cantons (states) and around 2.350 municipalities. The cantons and their municipalities vary in several aspects such as culture, population, geography, industrialization and urbanization. However, all cantons share a similar fiscal framework that is shaped by a strong tradition of fiscal autonomy, fiscal responsibility and direct voter participation in political decisions.

The direct democratic institutions most relevant for fiscal policy are voter initiatives and mandatory fiscal referenda. The latter are commonly triggered if a specified threshold related to one-time or recurring expenditure is exceeded. By means of initiatives, citizens can launch a ballot on self-formulated legislation if a sufficient number of signatures is collected. One of the oldest forms of direct democracy is still in place in the two rural cantons of Glarus and Appenzell Inner-Rhodes. In the so-called "Landsgemeinde" (cantonal meetings) all eligible citizens meet to vote on issues regarding constitutional and legislative matters among other things. Due to divergence in cantonal laws, direct democratic involvement varies substantially across cantons.

The large autonomy of the cantons is revealed by their high degree of fiscal decentralization. The cantonal share on public expenditure and revenue in Switzerland amounts to approximately $40 \%$, whereby half of the cantonal budget is spent on education and social security. Across all cantons, consumption spending amounts to $90 \%$ of cantonal total expenditure, while investment spending accounts for less than 10\%. To finance their activities, the cantons rely first and foremost on own taxes which rates can be chosen autonomously (tax bases are largely harmonized). While evidence suggests that cantons engage in tax competition, a ruinous race to the bottom does not occur (Feld, 2000; Feld and Kirchgässner, 2001c, 2003; Feld and Reulier, 2009).

In order to restrict cantonal finances, the Conference of Cantonal Finance Ministers passed a model law for cantonal budgeting in 1981. On the side of the current budget, the law requires a balanced budget in the medium term and a depreciation of balance sheet deficits by at least $20 \%$ annually. On the side of the investment budget, the model law restricts the self-financing ratio for net investments to at least $80 \%$ if net debt exceeds revenue by more than $100 \%$. The 
two budgetary accounts are interrelated as a further restrictive element requires depreciations of investments and of balance sheet deficits to be included in the current budget. Although the model law does not provide for cyclical adjustments, anti-cyclical fiscal policy is implicitly required as the law aims at medium term budget balance. Moreover, the requirement to repatriate balance sheet deficits implies incentives to accumulate savings (equity) in advance in order to cover deficits in later years. ${ }^{5}$

Throughout the last 35 years since the model law passed, the number of fiscally constrained cantons rose gradually and Appenzell Inner-Rhodes is now the one and only canton without a fiscal rule. As the design and stringency of the constraints vary widely, we follow Feld and Kirchgässner (2001a, 2008) and Feld et al. (2013) and take into account only credible fiscal rules that meet at least one of the following three minimum requirements: (I) a strong link between budget planning and execution, (II) a numeric deficit limit and (III) automatic sanctions. Overall, 18 cantons have been constrained by credible budget rules as of 2011. Based on extensive legal research we find that all 18 rules restrict the current budget but only three restrict the total budget, and 12 the investment budget (Table A.1). To be precise, the current budget restrictions predominantly aim at the cash flow, i.e., the current budget balance corrected for non-cash transactions.

As investment constraints often remain relatively weak or are non-existing, most debt brakes basically allow for a flight from the constrained current budget into the (unconstrained) investment account. To this end, politicians could lower the (implicit or explicit) capitalization limit that classifies expenditures as investments with the result that expenditure above that

\footnotetext{
${ }^{5}$ Figure A.1 illustrates the system of cantonal accounting. Simplified, the Handbook on the Harmonized Accounting Model for the Cantons and Communes (HAM2) requires the cantonal budget to be split up into two parts: the investment budget and the current budget (also called income statement or "Erfolgsrechnung"). The investment budget records revenue (primarily investment contributions from the federal level) and expenditure related to investments. The current budget records revenue and expenses related to consumption, whereas cash and noncash items are included. Non-cash transactions are pure bookkeeping entries without cash payments during the period and consist mainly of depreciations and of withdrawals or deposits from or into funds and special financing. A surplus (deficit) in the current budget increases (decreases) cantonal equity. Whenever a current deficit cannot be covered by equity, a balance sheet deficit ("Bilanzfehlbetrag") occurs. A canton with a balance sheet deficit, i.e., negative equity, would be bankrupt under private law. The current and investment budget are interrelated as, for instance, investment depreciations enter the current budget and a positive cash flow (current surplus corrected for non-cash transactions) stands ready to finance investments. If the cash flow is too small to cover total investment expenditure, the canton has to borrow. The self-financing ratio, i.e., the cash flow divided by net investments, indicates the share of cantonal investments financed by own means. For a detailed description refer to HAM2 (Conference of Cantonal Ministers of Finance, 2013). The model law for cantonal budgeting has been amended in 2015. The revised law does not require a depreciation of balance sheet deficits anymore. The law is available at: http://www.srscspcp.ch/srscspcp.nsf/go/a78ff96571bb620bc1257afe006b3fdb?OpenDocument\&lng=de.
} 
limit are not anymore recorded in the current budget but in the investment budget. A modification of the capitalization limit might even be dispensable as a serious detection of a violation is largely unlikely. Another possibility to circumvent the debt brake is the transmission of fiscal burden to the local level (Burret and Feld, 2014b).

Remarkably, one of the most restrictive debt brake, i.e., a fiscal rule that meets all three minimum requirements, was first set up over 85 years ago, on $17^{\text {th }}$ June 1929 , by the canton of St. Gall. ${ }^{6}$ The effectiveness of St Gall's fiscal law of 1929 is supported by anecdotal evidence. Public debt in St. Gall peaked one year after its adoption and started to decrease thereafter. On the contrary, all other cantons that had no credible fiscal rule in place showed a notably different debt development (Figure 1). Since it takes a considerable amount of time until a restraint exhibits its full impact, the slight debt reduction in the first years after the implementation of the new fiscal constraint is not surprising. Despite war-related costs, St. Gall managed to push its debt below pre-war levels by 1947. This remarkable debt reduction was not related to times of buoyant revenue but rather to considerable consolidation measures. To this end, taxes had been increased or newly implemented (e.g., stamp tax, inheritance tax, entertainment tax, poor tax, surcharge on federal taxes) and expenditure had been cut back (especially salaries). Later on, laws were adopted to cover exceptional expenditure and revenue shortfalls related to mobilization.

Figure 1 Development of Cantonal Debt in Swiss Francs per capita, 1905 - 1953

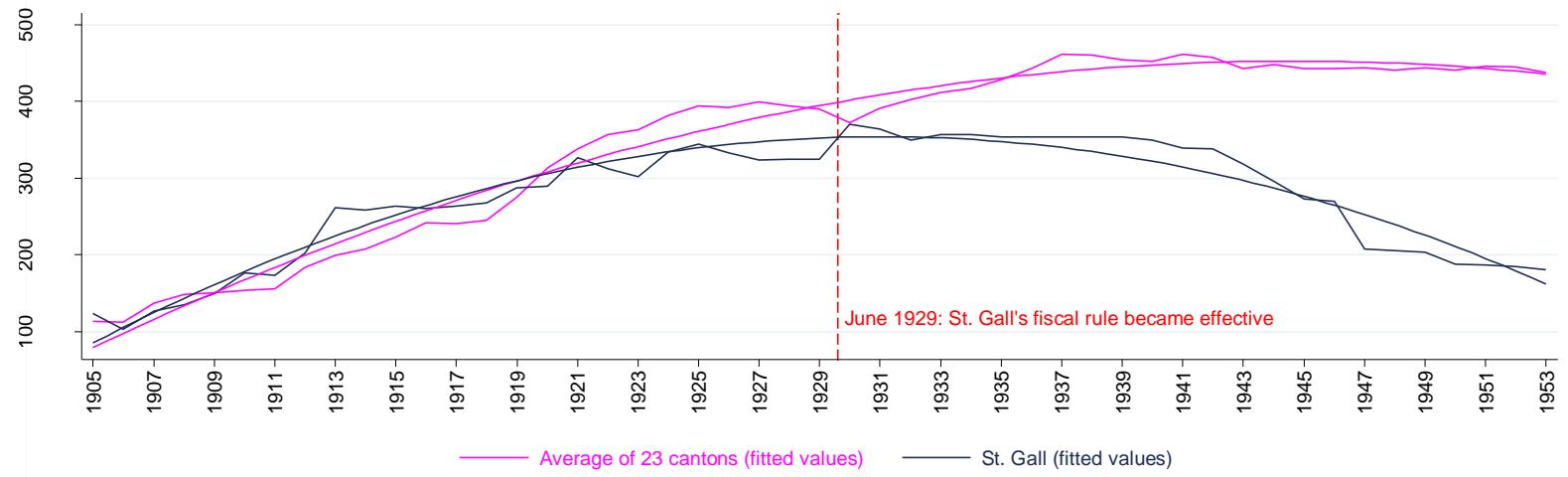

Average debt comprises all cantons but St. Gall and, due to data constraints, Glarus. Data refers to long-term debt, i.e., "feste Anleihen" for 1906-1919, "konsolidierte Schulden" for 1920-1929 "Anleihen und andere langfristige Schulden" for 1930 and "feste Schulden" for 1931-1954. Source: Schweizer Finanz-Jahrbücher.

\footnotetext{
${ }^{6}$ Besides the debt brake, the fiscal law of 1929 introduced fiscal referenda. Accordingly, one-time expenses above 800.000 Francs and recurring expenses above 100.000 Francs are subject to mandatory referenda.
} 


\section{Empirical Strategy and Model Specification}

To examine the effects of debt brakes, we gathered annual data of all 26 Swiss cantons over the period 1980-2011. The development of cantonal finances and the number of cantons with a debt brake are depicted in Figure 2. The cantonal expenditure and revenue increased over the period of interest, whereas cantonal debt and deficits accrued particularly during the economic turmoil of the 1990s and early 2000s. While debt brakes have only been in place in two cantons in the early 1980s, their number rose gradually. In 2005 almost every second canton had implemented a credible fiscal rule. In the same year a long-lasting debt reduction gained momentum, supporting a debt-containing impact of the rules. The staggered introduction of fiscal rules is exploited in a difference-in-differences approach.

Figure 2 Cantonal Finances in Real Swiss Francs per Capita and Number of Cantonal Debt Brakes, 1980-2011

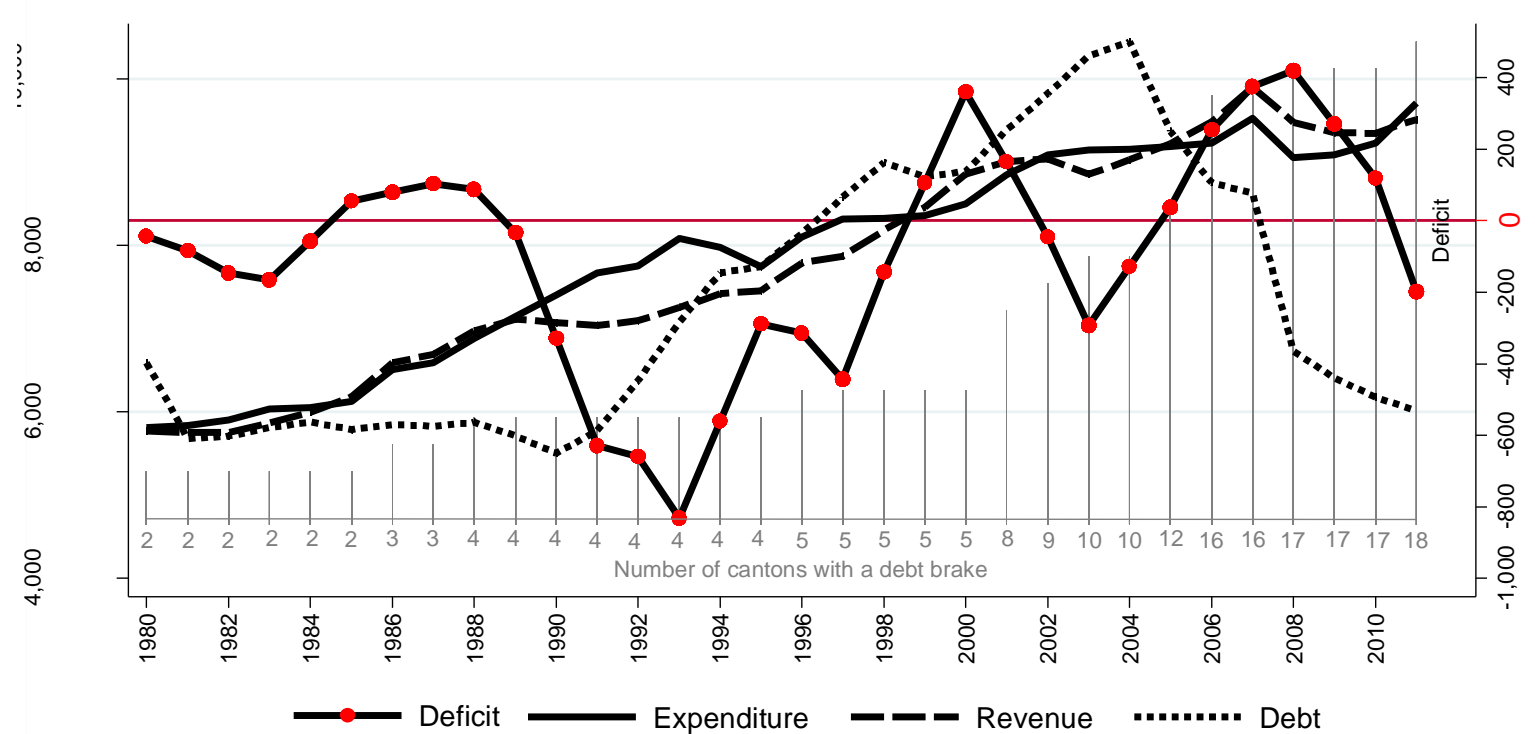

A negative (positive) value on the right axis indicates a deficit (surplus). Source: Swiss Federal Finance Administration and own research.

To render comprehensive insights possible, we examine a rich set of dependent fiscal variables and model specifications. Due to data restrictions, these differentiated data are available only since 1990. A first step reconsiders the impact of debt brakes on cantonal total revenue, expenditure, debt and deficit (Section 5.1). The budget balance variable is derived by subtracting total revenue from total expenditure such that a deficit has a positive and a surplus a negative sign. As most rules restrict the (adjusted) current budget rather than the total budget, a second step examines whether the impact of debt brakes on cantonal finances is stronger if we consider more narrowly defined fiscal variables that correspond better with the variables targeted by the rules (Section 5.2). The dependent variables are investment spending, consumption spending, current spending, spending by functional category, depreciation 
expense, cash flow deficit, current deficit and the balance of fund and special financing as defined in Table 2. Again, the budget balance variables have a positive sign in case of a deficit. Regarding depreciation expense we expect a positive effect of fiscal rules for two reasons. First, the rules' commonly require a depreciation of budget deficits and investments. Second, in order to reach a balanced budget in the medium term, i.e., to satisfy their debt brake, it might be viable for cantonal governments to hide surpluses from calls for new spending by means of additional depreciation charges (Clémenceau, 2014, Clémenceau and Soguel, 2014).

Table 2 Definition of Cantonal Spending and Deficit Variables

\begin{tabular}{|c|c|c|c|}
\hline & \multicolumn{3}{|c|}{ Total budget } \\
\hline & \multicolumn{2}{|c|}{ Current budget } & \multirow[t]{2}{*}{ Investment budget } \\
\hline & Cash items & Non-cash items & \\
\hline \multicolumn{4}{|l|}{ EXPENDITURE VARIABLES } \\
\hline Total spending & $\checkmark$ & & $\checkmark$ \\
\hline Investment spending & & & $\checkmark$ \\
\hline Consumption spending* & $\checkmark$ & & \\
\hline Current spending* & $\checkmark$ & $\checkmark$ & \\
\hline Total spending by category & $\checkmark$ & & $\checkmark$ \\
\hline Depreciation expense* & & $\checkmark$ (only depreciations) & \\
\hline \multicolumn{4}{|l|}{ DEFICIT VARIABLES } \\
\hline Total deficit & $\checkmark$ & & $\checkmark$ \\
\hline Current deficit* & $\checkmark$ & $\checkmark$ & \\
\hline Cash flow deficit* & $\checkmark$ & & \\
\hline Funds and special financing balance* & & $\checkmark$ (only special financing) & \\
\hline
\end{tabular}

In a third step we scrutinize whether cantonal budget rules are associated with evasive reactions (Section 5.3). An evasion into funds and special financing is hardly possible, as the balance of these activities has to be recorded in the current budget by the end of the year. ${ }^{7}$ However, cantonal governments could evade their debt brake by (re-)classifying consumption spending as investment since debt brakes commonly put much stronger constraints on the current budget than on the investment budget - if the latter is restricted at all. To study this kind of fiscal trickery, we scrutinize the rules' effect on investment spending and on the ratio between investment and total spending. Furthermore, we investigate whether cantonal debt brakes induce governments to shift deficits to the local level.

As we expect the fiscal rules to restrict the politicians' ability to run deficits, a fourth step investigates the relation between debt brakes and political budget cycles (Section 5.4). During the period of interest, 216 cantonal governments have been appointed for a period of mostly

\footnotetext{
${ }^{7}$ We do not find a significant effect of cantonal debt brakes on funds and special financing (results upon request).
} 
four or five years. An exception is Appenzell Inner-Rhodes as the government is still elected in the cantonal meeting - since 1999 annually.

A last step evaluates the fiscal effects of cantonal debt brakes conditional on the presence of negative fiscal shocks (Section 5.5). This test provides us with insights into the flexibility of debt brakes and the relative use of tax and spending adjustments to address cantonal deficit shocks. Given that debt brakes commonly require a balanced budget, we expect the constraints to induce cantonal governments to adjust revenue and spending as soon as a deficit shock is imminent, i.e., within the same fiscal year. Inspired by Poterba (1994) and Poterba and Rueben (1999, 2001), we define an unexpected deficit shock as actual expenditure exceeding forecasted expenditure and actual revenue falling behind the projections. We find 149 deficit shocks in the period 1984-2011 that cluster particularly during the economic turmoil of the 1990s as well as in the cantons of Geneva and Bern (Figure A.2).

To capture the effects of the cantonal fiscal rules, our interest is mainly on a dummy which equals one if a canton has a debt brake in place in a given year and zero otherwise. To account for the extent of cantonal direct democracy we include (1) a binary variable which equals one if mandatory fiscal referenda exist and zero otherwise, (2) the spending threshold per capita that triggers the mandatory referenda if exceeded and (3) the number of signatures per 1.000 inhabitants that are required for cantonal initiatives.

The economic situation is captured by the unemployment rate, the taxable income and the relative taxable income of a canton. In addition we control for the amount of unconditional federal aid per capita (i.e. the cantonal share in federal receipts). The socio-demographic situation is mapped by population size, the share of elderly, the share of young residents and the share of German speaking citizens. Moreover, the ideology in parliament is measured by the share of seats held by left-wing parties. ${ }^{8}$

In particular, we estimate the following baseline equation:

[1] $\quad Y_{c, t}=\beta_{0}+\beta_{1}$ DebtBrake $_{c, t}+\beta_{2}$ MandatoryReferendum $_{c, t}+\beta_{3}$ SpendingThreshold $_{c, t}+$ $\beta_{4}$ SignatureRequirement $_{c, t}+\beta_{5}$ Unemployment $_{c, t}+\beta_{6}$ Income $_{c, t}+\beta_{7}$ Relativelncome $_{c, t}+$

\footnotetext{
8 These institutional, economic, socio-demographic and political controls are common in relevant literature. For a broader discussion of our controls see, e.g., Roubini and Sachs (1989a, 1989b), De Haan and Sturm (1994), Shadbegian (1996) and Feld and Kirchgässner (2001a, 2001b, 2008). The size of government and of parliament is not taken into account since these variables hardly vary across time.
} 


$$
\begin{aligned}
& \beta_{8} \text {FFederalAid }_{c, t}+\beta_{9} \text { Pop }_{c, t}+\beta_{10} \text { ShareOld }_{c, t}+\beta_{11} \text { ShareYoung }_{c, t}+\beta_{12} \text { ShareGerman }_{c, t}+ \\
& \beta_{13} \text { Ideology }_{c, t}+\gamma_{c}+\tau_{t}+\varepsilon_{c, t}
\end{aligned}
$$

where $t$ indicates the year and $c$ the canton. As discussed above, various fiscal indicators are employed as dependent variable Y. It is expressed in real Swiss Francs per capita in all cases. A detailed description and the source of the data are given in Table A.2. ${ }^{9}$

Table A. 3 shows the summary statistics and presents the mean value of each variable separately for cantons with and without a debt brake. Equal means of the treatment group (cantons with a debt brake) and control group (cantons without a debt brake) are rejected with respect to most variables by a simple t-test illustrating that cantonal debt brakes might matter. Interestingly, the mean values of debt and deficit are significantly smaller in the treatment group than in the control group. This can be taken as preliminary evidence that cantonal debt brakes support sound public finances.

Unlike most previous studies, our baseline model includes canton $\left(\gamma_{c}\right)$ and year $\left(\tau_{t}\right)$ fixed effects to account for unobserved heterogeneity across cantons and time-specific factors. The application is rendered possible as we observe up to 18 staggered introduced cantonal debt brakes and a rather large institutional variation. The two-way fixed effects estimation is commonly seen as a generalization of the difference-in-differences approach as both methods basically eliminate time trends affecting all cantons and time-constant differences across the cantons. A key assumption for such a research design is that the treatment and control group would follow a common trend in the absence of treatment. While this is obviously not observable for the treated, similar fiscal trends before the treatment strengthen the validity of the difference-in-differences estimates (Figure A.3). In addition, the common political, cultural and constitutional Swiss framework adds to the credibility of the common trend assumption. ${ }^{10}$

Endogeneity issues are relatively unlikely as the dependent and explanatory variables are measured within the same year. An exception might be cantonal debt which is influenced by previous years' budget balance. Moreover, fiscal institutions such as debt brakes and direct democracy are commonly subject to cantonal referenda such that correlations could be driven by voters' or legislatures' fiscal preferences (Poterba, 1996). However, the problem of omitted

\footnotetext{
${ }^{9}$ Similar findings obtain if a log transformation is employed instead of per capita values (results upon request).

${ }^{10} \mathrm{~A}$ robustness test excludes Basel-City and Geneva as their finances stand out from the rest. In addition, a model without cantonal fixed effects is estimated as robustness check.
} 
variables is mitigated for several reasons. First, the preferences can be assumed to be rather homogenous as we analyze a single country with a common framework. Second, Dafflon and Pujol (2001) suggest that preferences are largely time-invariant and are, thus, captured by fixed effects. Third, Krogstrup and Wälti (2008) explicitly show that accounting for fiscal preferences has no substantial impact on the effect of debt brakes on cantonal deficits. Fourth, our ideology variable approximates fiscal preferences.

As we have panel data, it is crucial to cope with concerns of biased standard errors due to autocorrelation of the error terms. To allow observations to be correlated within each canton, we cluster standard errors at the cantonal level and correct them for heteroscedasticity. In addition, we followed Cameron et al. (2011) allowing for correlations among cantons in the same year and among different years in the same canton using non-nested two-way clustering at the cantonal and year level. While clustering is problematic if the number of clusters is small, we follow Luechinger and Schaltegger (2013) who analyze a dataset similar to ours and conclude that we have just enough clusters. To dispel doubts on the matter, we additionally report $p$-values based on the wild-cluster bootstrap-t procedure. The resampling method has the advantages of working well in cases with few clusters and unbalanced cluster sizes (Cameron et al., 2008; Cameron and Miller, 2015) and of producing results quite robust to variations in the number of clusters treated (MacKinnon and Webb, 2015). The bootstrapped p-values are the most unfriendly to our analysis and, thus, a hard sensitivity test. Finally, we overcome a widespread shortcoming in the interpretation of interaction terms by reporting marginal effects together with their standard errors (Brambor et al., 2006). ${ }^{11}$

\section{Baseline Results ${ }^{12}$}

\subsection{Total Budget Variables}

Table 3 illustrates the effects of cantonal fiscal institutions on total budget variables. All equations include cantonal and year fixed effects as suggested by Wald tests. The model explains almost $85 \%$ of the total variance of the response data in the expenditure and revenue

\footnotetext{
${ }^{11}$ The wild-cluster bootstrap-t procedure uses the wild bootstrap to resample clusters of residuals obtained from regressions and re-estimates the original equation with the newly generated residuals. See Cameron et al. (2008) for details. We employ the Stata post-estimation command "bootwildct" provided by Malde (2012) with 1000 repetitions. Furthermore, average marginal effects are calculated based on regressions with cantonal clustered standard errors.

${ }^{12}$ For all estimations we used Stata 13.1. In the interest of clarity, the illustration and discussion of the results is primarily restricted to the cantonal debt brakes.
} 
equation (column I and II). In the case of debt and deficits the regression line approximates the real data points less well with an adjusted R2 of 0.42 and 0.33 (column III and IV). In line with preliminary evidence, we find that fiscal rules are associated with significantly increased revenue and significantly decreased debt and deficit.

Table 3 Effects of Cantonal Debt Brakes on Total Budget Variables, 1980-2011

\begin{tabular}{|c|c|c|c|c|c|}
\hline & $\begin{array}{r}\text { Cantonal } \\
\text { expenditure }\end{array}$ & $\begin{array}{r}\text { II } \\
\text { Cantonal } \\
\text { revenue } \\
\end{array}$ & $\begin{array}{r}\text { III } \\
\text { Cantonal } \\
\text { debt } \\
\end{array}$ & $\begin{array}{r}\mathrm{IV} \\
\text { Cantonal } \\
\text { deficit } \\
\end{array}$ & $\begin{array}{r}\mathrm{V} \\
\text { Combined } \\
\text { deficit } \\
\end{array}$ \\
\hline Debt brake & $\begin{array}{r}185.763 \\
(1.102) \\
[0.262]\{0.318\}]\end{array}$ & $\begin{array}{r}411.037^{* *} \\
(2.076) \\
{[0.033]\{0.048\}}\end{array}$ & $\begin{array}{r}-1034.600 * * \\
(-2.322) \\
{[0.064]\{0.066\}}\end{array}$ & $\begin{array}{r}-225.274^{* *} \\
(-2.664) \\
{[0.017]\{0.020\}}\end{array}$ & $\begin{array}{r}-312.063 * * \\
(-2.746) \\
{[0.007]\{0.014\}}\end{array}$ \\
\hline Signatures initiative & $\begin{array}{r}-1.135 \\
(-0.056) \\
{[0.953]\{0.952\}}\end{array}$ & $\begin{array}{r}-5.360 \\
(-0.251) \\
{[0.804]\{0.787\}}\end{array}$ & $\begin{array}{r}183.872 * \\
(1.857) \\
{[0.072]\{0.166\}}\end{array}$ & $\begin{array}{r}4.225 \\
(0.430) \\
{[0.696]\{0.687\}}\end{array}$ & $\begin{array}{r}4.041 \\
(0.304) \\
{[0.775]\{0.813\}}\end{array}$ \\
\hline Spending threshold & $\begin{array}{r}8.425^{* * *} \\
(9.519) \\
{[0.000]\{0.060\}}\end{array}$ & $\begin{array}{r}8.820 * * * \\
(9.277) \\
{[0.000]\{0.098\}}\end{array}$ & $\begin{array}{r}5.562 \\
(1.439) \\
{[0.202]\{0.759\}}\end{array}$ & $\begin{array}{r}-0.394 \\
(-0.947) \\
{[0.490]\{0.819\}}\end{array}$ & $\begin{array}{r}-0.483 \\
(-0.835) \\
{[0.485]\{0.903\}}\end{array}$ \\
\hline Referendum dummy & $\begin{array}{r}-292.311 \\
(-1.596) \\
{[0.164]\{0.286\}}\end{array}$ & $\begin{array}{r}-317.855 \\
(-1.453) \\
{[0.165]\{0.268\}}\end{array}$ & $\begin{array}{r}625.830 \\
(0.505) \\
{[0.617]\{0.656\}}\end{array}$ & $\begin{array}{r}25.544 \\
(0.220) \\
{[0.832]\{0.809\}}\end{array}$ & $\begin{array}{r}58.372 \\
(0.409) \\
{[0.693]\{0.656\}}\end{array}$ \\
\hline Controls & Yes & Yes & Yes & Yes & Ye \\
\hline Two-way FE & Yes & Yes & Yes & Yes & Ye \\
\hline Adj. R2 & 0.83 & 0.84 & 0.42 & 0.33 & 0.38 \\
\hline Obs. & 832 & 832 & 832 & 832 & 832 \\
\hline Wald test: FE & $283 * * *$ & $567 * * *$ & $322 * * *$ & $23 * * *$ & $124^{* *}$ \\
\hline
\end{tabular}

Besides the variables shown, we employ all controls as in the baseline equation [1]. Full regression bodies available in the online appendix. The numbers in parentheses indicate the estimated t-statistics for standard errors that are adjusted for clustering at the cantonal level and corrected for heteroscedasticity. These values are used to determine statistical significance: $*^{p}<0.1$ (significance at the $10 \%$ level), $* * p<0.05$ (significance at the $5 \%$ level), and $* * * p<0.01$ (significance at the $1 \%$ level). The numbers in square brackets indicate the estimated $p$-values that are adjusted for non-nested clustering at the cantonal and year level. The numbers in braces indicate the estimated $\mathrm{p}$-values using the wild-cluster bootstrap-t procedure. The Wald test has the null hypothesis that the fixed effects are jointly equal to zero (F-statistic based on regressions with cluster-robust standard errors).

Analogous to the debt brakes, cantonal direct democracy is meaningful for public finances. The insignificance of the referenda dummy is not puzzling as the spending threshold variable, which is an interaction term with the referenda dummy, is highly significant. Taken together the two variables suggest that mandatory referenda restrict expenditure and revenue - the better, the lower the spending threshold is. ${ }^{13}$ Similarly, Funk and Gathmann (2011), neglecting the spending threshold, find a significant negative effect of budget referenda on cantonal expenditure. To exemplify, a relatively low spending threshold of 150'000 Swiss Francs (less than one Swiss Franc per capita) has been in place in Solothurn during most of the 1980s. In contrast, mandatory referenda in Jura are only triggered if spending projects exceed 47 million

\footnotetext{
${ }^{13} \mathrm{~A}$ Wald test rejects that the referenda dummy and spending threshold variable are jointly equal to zero at the $1 \%$ significance level. It should also be noted that fiscal referenda have not changed much during the time period under consideration The FE specification is particularly unfriendly to such almost time-invariant variables such that the estimated effects depend only on a small number of cantons.
} 
Swiss Francs (around 670 Swiss Francs per capita in 2012). While the number of signatures that is required for cantonal initiatives shows a positive impact on cantonal debt, its statistical significance is ambiguous.

In sum, the findings confirm previous research: Cantonal fiscal institutions - be it debt brakes or fiscal referenda - are associated with sound public finances. This largely holds irrespectively of whether we base our statistical inference on cantonal clustered standard errors (corresponding t-statistic in parentheses), on two-way clustered standard errors ( $p$-values in square brackets) or on the more conservative bootstrapped p-values (in braces).

\subsection{Specific Budget Components}

As previous results suggest that fiscal rules are highly relevant for total deficit, we subsequently examine whether the estimated effect can be attributed to specific deficit and expenditure components.

Analogous to the total deficit equation, cantonal debt brakes show a significant negative effect on the more narrowly defined deficit variables (Table 4, column I-IV). The impact is most negative and most significant in the equation of the cantonal cash flow deficit (column III). This finding seems reasonable given that the cantonal debt brakes primarily restrict the cash flow deficit. The relatively weaker effect of debt brakes on the current deficit (column I) is possibly due to the increased depreciation expenses (column $V$ ). The increase in the latter could be explained by the rules' requirement to depreciate fiscal deficits and investments. Similar to depreciations, the non-cash balance of funds and special financing is positively, though not significantly, affected by fiscal rules (results upon request). The differentiated effect on the deficit variables emphasize the importance to distinguish between a direct effect of fiscal rules on the targeted variable and an indirect effect on non-restricted variables.

Regarding the effect of cantonal debt brakes on the different expenditure components, the results are mixed. One the one side no significant effects of fiscal rules obtain for consumption spending (column VI), current spending (results upon request) and spending by functional category (results upon request). On the other side, debt brakes are associated with significantly increased investment spending (column VII). Thus, evidence clearly rejects the common claim that debt brakes hurt investments. A similar conclusion is drawn for the debt brake on the Swiss federal level (Bundesrat 2013). Noteworthy, direct democratic institutions are, in analogy to the previous results, particularly relevant for cantonal spending. 
In sum, the results suggest that cantonal debt brakes reduce public deficits. The impact is stronger, the better the analyzed deficit component corresponds with the variable targeted by the rule, i.e., the cash flow deficit. However, the findings also indicate that fiscal rules might evoke an expansion of investment spending. This twofold effect could possibly hint to a flight from the constrained current budget into the (unconstrained) investment budget. This issue is investigated in the next Section.

Table 4 Effects of Cantonal Debt Brakes on Specific Budget Components, various periods

\begin{tabular}{|c|c|c|c|c|c|c|c|}
\hline & \multicolumn{5}{|c|}{$1990-2011$} & \multicolumn{2}{|c|}{$1980-2011$} \\
\hline & I & II & III & IV & $\mathrm{V}$ & VI & VII \\
\hline & $\begin{array}{r}\text { Cantonal current } \\
\text { deficit }\end{array}$ & $\begin{array}{r}\text { Combined } \\
\text { current deficit }\end{array}$ & $\begin{array}{r}\text { Cantonal } \\
\text { cash flow def. }\end{array}$ & $\begin{array}{r}\text { Combined cash } \\
\text { flow def. }\end{array}$ & $\begin{array}{r}\text { Cantonal } \\
\text { depreciation }\end{array}$ & $\begin{array}{c}\text { Cantonal } \\
\text { consum. exp. }\end{array}$ & $\begin{array}{l}\text { Cantonal } \\
\text { invest. exp. }\end{array}$ \\
\hline Debt brake & $\begin{array}{r}-211.369^{*} \\
(-1.781) \\
{[0.078]\{0.092\}}\end{array}$ & $\begin{array}{r}-307.897^{* *} \\
(-2.307) \\
{[0.020]\{0.024\}}\end{array}$ & $\begin{array}{r}-283.163^{* *} \\
(-2.680) \\
{[0.012]\{0.008\}}\end{array}$ & $\begin{array}{r}-428.240^{* * *} \\
(-3.506) \\
{[0.001]\{0.002\}}\end{array}$ & $\begin{array}{r}107.709^{*} \\
(1.943) \\
{[0.029]\{0.064\}}\end{array}$ & $\begin{array}{r}-68.053 \\
(-0.534) \\
{[0.592]\{0.589\}}\end{array}$ & $\begin{array}{r}253.815^{* *} \\
(2.611) \\
{[0.022]\{0.008\}}\end{array}$ \\
\hline $\begin{array}{l}\text { Signatures } \\
\text { initiative }\end{array}$ & $\begin{array}{r}-7.885 \\
(-0.795) \\
{[0.422]\{0.445\}}\end{array}$ & $\begin{array}{r}-4.474 \\
(-0.345) \\
{[0.726]\{0.715\}}\end{array}$ & $\begin{array}{r}-5.015 \\
(-0.364) \\
{[0.740]\{0.787\}}\end{array}$ & $\begin{array}{r}-0.144 \\
(-0.009) \\
{[0.994]\{0.961\}}\end{array}$ & $\begin{array}{r}-2.873 \\
(-0.398) \\
{[0.688]\{0.739\}}\end{array}$ & $\begin{array}{r}-24.591 \\
(-1.388) \\
{[0.137]\{0.363\}}\end{array}$ & $\begin{array}{r}23.456^{* * *} \\
(3.007) \\
{[0.002]\{0.046\}}\end{array}$ \\
\hline $\begin{array}{l}\text { Spending } \\
\text { threshold }\end{array}$ & $\begin{array}{r}-0.371 \\
(-0.670) \\
{[0.607]\{0.519\}}\end{array}$ & $\begin{array}{r}-0.061 \\
(-0.074) \\
{[0.938]\{0.961\}}\end{array}$ & $\begin{array}{r}-1.791^{*} \\
(-1.750) \\
{[0.226]\{0.633\}}\end{array}$ & $\begin{array}{r}-2.062^{*} \\
(-1.906) \\
{[0.123]\{0.513\}}\end{array}$ & $\begin{array}{r}0.916 \\
(1.169) \\
{[0.350]\{0.809\}}\end{array}$ & $\begin{array}{r}3.082^{* * *} \\
(5.638) \\
{[0.000]\{0.000\}}\end{array}$ & $\begin{array}{r}5.343^{* * *} \\
(9.755) \\
{[0.000]\{0.068\}}\end{array}$ \\
\hline $\begin{array}{l}\text { Referendum } \\
\text { dummy }\end{array}$ & $\begin{array}{r}-81.868 \\
(-0.514) \\
{[0.617]\{0.621\}}\end{array}$ & $\begin{array}{r}-0.668 \\
(-0.003) \\
{[0.998]\{0.979\}}\end{array}$ & $\begin{array}{r}-55.790 \\
(-0.335) \\
{[0.749]\{0.769\}}\end{array}$ & $\begin{array}{r}73.664 \\
(0.337) \\
{[0.746]\{0.749\}}\end{array}$ & $\begin{array}{r}42.707 \\
(0.586) \\
{[0.512]\{0.655\}}\end{array}$ & $\begin{array}{r}-206.155 \\
(-1.113) \\
{[0.267]\{0.284\}}\end{array}$ & $\begin{array}{r}-86.156 \\
(-0.844) \\
{[0.506]\{0.470\}}\end{array}$ \\
\hline Controls & Yes & Yes & Yes & Yes & Yes & Yes & Yes \\
\hline Two-way FE & Yes & Yes & Yes & Yes & Yes & Yes & Yes \\
\hline Adj. R2 & 0.28 & 0.27 & 0.27 & 0.32 & 0.15 & 0.91 & 0.30 \\
\hline Obs. & 572 & 572 & 572 & 572 & 572 & 832 & 832 \\
\hline Wald test FE & $16^{* * *}$ & $20 * * *$ & $47 * * *$ & $91^{* * *}$ & $141^{* * *}$ & $721 * * *$ & $889 * * *$ \\
\hline
\end{tabular}

\subsection{Evasive Reactions: Unintended effects of fiscal rules}

\section{Evasion into the Investment Budget?}

The previous results raise the question as to whether cantonal governments circumvent their debt brake by exploiting the weak or non-existing investment constraints. A flight into the investment budget is particularly attractive as investment projects can be seen as a prime example of pork barrel politics. As such an evasion strategy might be less tempting if investments are restricted, we additionally employ a binary indicator that is one if a canton has an investment restriction in place in a given year and zero otherwise and interact it with the debt brake dummy. ${ }^{14}$

We find that investment spending is only significantly increased by cantonal debt brakes if the investment budget is left unconstraint (Table 5, column II). The coefficient of the investment

\footnotetext{
${ }^{14}$ We define an investment restriction as a law that requires a self-financing ratio for investments, a balanced investment account or a balanced total account. Alternatively, a rule is classified as an investment restriction if it stipulates a short deprecation period together with a restriction of the current budget (Table A.1).
} 
rule shows the expected negative sign. Its insignificance is hardly surprising as the investment constraints are rather weak.

In a next step, we explore whether the increased investment expenditure can be attributed to some kind of shift from consumption spending to investment spending. To this end, we employ investment spending relative to total spending, i.e., the investment ratio, as dependent variable. While we find that debt brakes can be associated with a larger investment ratio, i.e., more investment spending relative to total spending, the finding is questioned as the coefficient is only significant at the $10 \%$ level and alternatively calculated $p$-values are ambiguous (column III). Moreover, the debt brake coefficient becomes statistically insignificant once we add the dummy for investment rules (column IV) and the interaction term (column V).

We conclude that cantonal debt brakes exhibit some indirect effects inducing politicians to increase investment spending if the investment budget is left unconstrained. While this increase possibly hints to some kind of creative accounting, it is not at the expense of consumption spending. Finally, the results emphasize the importance that fiscal rules cover all accounts.

Table 5 Evasive Reactions to Cantonal Debt Brakes, 1980-2011

\begin{tabular}{|c|c|c|c|c|c|}
\hline & I & II & III & IV & $\bar{V}$ \\
\hline & Investm. exp. & Investm. exp. & Investm. ratio & Investm. ratio & Investm. ratio \\
\hline Debt brake & $\begin{array}{r}289.095^{* *} \\
(2.170) \\
{[0.033]} \\
\{0.026\}\end{array}$ & $\begin{array}{r}231.829 * * \\
(2.382) \\
{[0.019]} \\
\{0.012\}\end{array}$ & $\begin{array}{l}0.020^{*} \\
(1.863) \\
{[0.067]} \\
\{0.104\}\end{array}$ & $\begin{array}{r}0.023 \\
(1.708) \\
{[0.093]} \\
\{0.148\}\end{array}$ & $\begin{array}{r}0.017 \\
(1.431) \\
{[0.160]} \\
\{0.206\}\end{array}$ \\
\hline Investment rule & $\begin{array}{r}-137.174 \\
(-0.700) \\
{[0.491]} \\
\{0.603\}\end{array}$ & $\begin{array}{r}-321.638 \\
(-0.732) \\
{[0.472]} \\
\{0.789\}\end{array}$ & & $\begin{array}{r}-0.010 \\
(-0.544) \\
{[0.593]} \\
\{0.631\}\end{array}$ & $\begin{array}{r}-0.029 \\
(-0.785) \\
{[0.440]} \\
\{0.709\}\end{array}$ \\
\hline $\begin{array}{l}\text { Average marginal effect of debt } \\
\text { brake if investment rule }=1\end{array}$ & & $\begin{array}{r}489.695 \\
(1.172)\end{array}$ & & & $\begin{array}{r}0.043 \\
(0.221)\end{array}$ \\
\hline Controls & Yes & Yes & Yes & Yes & Yes \\
\hline Two-way FE & Yes & Yes & Yes & Yes & Yes \\
\hline Adj. R2 & 0.30 & 0.31 & 0.59 & 0.59 & 0.60 \\
\hline Obs. (Clusters) & 832 & 832 & 832 & 832 & 832 \\
\hline Wald test: FE & $1016 * * *$ & $283 * * *$ & $1323 * * *$ & $39 * * *$ & $121 * * *$ \\
\hline
\end{tabular}

\section{Shifting Fiscal Burden to Municipalities?}

In order to determine whether cantonal governments evade their fiscal constraints by shifting deficits to the local level, we follow Feld and Kirchgässner (2008) comparing the debt brake coefficient in the deficit equation that is only based on cantonal data with the coefficient in the deficit equation that is based on combined data of the cantonal and municipal level. While the 
direction of the impact is the same negative one in all deficit equations, the debt brake coefficient is quantitatively larger in absolute terms and more significant if the combined deficit of the cantonal and local level is employed. This holds irrespectively of whether we consider total deficit (Table 3, column IV and V), current deficit (Table 4, column I and II) or cash flow deficit (Table 4, column III and IV). A Wald test rejects equality of the two corresponding debt brake coefficients in case of total deficit (p-value 0.052), cash flow deficit ( $p$-value 0.000) and current deficit ( $p$-value 0.008).

In sum, evidence suggests that debt brakes are not associated with a shift of deficits from cantons to their municipalities but rather with enhanced fiscal discipline on the local level of governments. This even holds in years of cantonal elections (Table 6). The finding could be explained by the statutory cantonal responsibility for municipal finances that may be taken more seriously subsequent to a cantonal debt brake introduction. Corresponding evidence is presented by Feld and Kirchgässner (2008) and Burret and Feld (2014b).

\subsection{Political Budget Cycles}

To map the influence of fiscal rules on political budget cycles we interact the debt brake with a dummy for election years (Table 6). Adding the interaction term and the two constitutive terms largely confirms our baseline findings, i.e. debt brakes support sound finances. Unlike previous studies, we find evidence that cantonal politicians (ab)use fiscal policy instruments in order to maximize popular support. However, this effect is conditional on a debt brake being in place or not: The marginal effects of the interaction term suggest that deficits significantly increase in election years only if cantonal finances are not constrained by a debt brake. Thus, cantonal debt brakes can mitigate political budget cycles as they are particularly effective during elections.

While total spending is not affected by elections, investment spending is estimated to significantly increase during elections if a debt brake is present. In line with our results on evasive reactions, the finding suggests that cantonal debt brakes induce politicians to particularly manipulate investment spending for electoral purpose. This could possibly hint to some kind of electoral cycle in accounting gimmicks. 
Table 6 Political Budget Cycles and Debt Brakes, various periods

\begin{tabular}{|c|c|c|c|c|c|c|c|c|c|c|c|c|}
\hline & \multicolumn{7}{|c|}{$1980-2011$} & \multicolumn{5}{|c|}{$1990-2011$} \\
\hline & $\begin{array}{l}\text { Total } \\
\text { exp. }\end{array}$ & $\begin{array}{r}\text { Total } \\
\text { rev. }\end{array}$ & $\begin{array}{c:}\text { Total } \\
\text { debt }\end{array}$ & $\begin{array}{r:r}\text { Total } \\
\text { deficit }\end{array}$ & $\begin{array}{l}\text { Combined } \\
\text { total def. }\end{array}$ & \begin{tabular}{r|} 
Invest. \\
exp.
\end{tabular} & $\begin{array}{r}\text { Consum. } \\
\text { exp. }\end{array}$ & $\begin{array}{r}\text { Current } \\
\text { deficit }\end{array}$ & $\begin{array}{l}\text { Combined } \\
\text { current def. }\end{array}$ & $\begin{array}{r}\text { Cash flow } \\
\text { deficit }\end{array}$ & $\begin{array}{l}\text { Combined } \\
\text { cash flow def. }\end{array}$ & $\begin{array}{r}\text { Depreciation } \\
\text { expense }\end{array}$ \\
\hline Debt brake & $\begin{array}{r}174.857 \\
(1.052)\end{array}$ & $\begin{array}{r}398.818^{*} \\
(2.032)\end{array}$ & \begin{tabular}{r|r}
$-948.850 *$ & \\
$(-2.014)$ &
\end{tabular} & \begin{tabular}{r|r}
$-223.961^{* *}$ \\
$(-2.694)$
\end{tabular} & $\begin{array}{r}-310.046^{* *} \\
(-2.708)\end{array}$ & $\begin{array}{r}250.254^{* *} \\
(2.520)\end{array}$ & $\begin{array}{l}-75.397 \\
(-0.604)\end{array}$ & $\begin{array}{r}-196.587 \\
(-1.622)\end{array}$ & $\begin{array}{r}-296.880^{* *} \\
(-2.223)\end{array}$ & $\begin{array}{r}-271.878^{* *} \\
(-2.534)\end{array}$ & $\begin{array}{r}-410.292 * * * \\
(-3.335)\end{array}$ & $\begin{array}{r}109.516^{*} \\
(1.925)\end{array}$ \\
\hline Election year & $\begin{array}{l}36.407 \\
(1.121)\end{array}$ & $\begin{array}{l}-43.058 \\
(-1.037)\end{array}$ & \begin{tabular}{l|l}
-72.233 & \\
$(-0.474)$ &
\end{tabular} & \begin{tabular}{r|r}
$79.464^{* * *}$ & \\
$(3.309)$ &
\end{tabular} & $\begin{array}{r}82.212 * * * \\
(2.959)\end{array}$ & \begin{tabular}{l|l}
39.672 & \\
$(1.122)$ &
\end{tabular} & $\begin{array}{r}-3.265 \\
(-0.141)\end{array}$ & $\begin{array}{l}58.250 \\
(1.685)\end{array}$ & $\begin{array}{l}55.326 \\
(1.441)\end{array}$ & $\begin{array}{r}79.451^{* * *} \\
(2.851)\end{array}$ & $\begin{array}{r}94.929 * * \\
(2.702)\end{array}$ & $\begin{array}{r}5.028 \\
(0.223)\end{array}$ \\
\hline $\begin{array}{l}\text { Average marginal effect } \\
\quad \text { of election if debt brake }=1\end{array}$ & $\begin{array}{l}83.128 \\
(1.161)\end{array}$ & $\begin{array}{r}3.968 \\
(0.059)\end{array}$ & $\begin{array}{r}-426.005 \\
(-1.212)\end{array}$ & \begin{tabular}{l|l}
79.160 & \\
$(1.088)$ &
\end{tabular} & $\begin{array}{l}79.214 \\
(0.897)\end{array}$ & $\begin{array}{r}56.693^{* *} \\
(2.456)\end{array}$ & $\begin{array}{l}26.434 \\
(0.382)\end{array}$ & $\begin{array}{r}0.010 \\
(0.000)\end{array}$ & $\begin{array}{l}12.774 \\
(0.144)\end{array}$ & $\begin{array}{l}37.489 \\
(0.513)\end{array}$ & $\begin{array}{l}25.944 \\
(0.301)\end{array}$ & $\begin{array}{r}-2.240 \\
(-0.045)\end{array}$ \\
\hline of debt brake if election $=1$ & $\begin{array}{r}221.578 \\
(1.160)\end{array}$ & $\begin{array}{r}445.843^{* *} \\
(2.069)\end{array}$ & $\begin{array}{r}-1302.622 * * \\
(-2.532)\end{array}$ & $\begin{array}{r}-224.266^{* *} \\
(-2.102)\end{array}$ & $\begin{array}{r}-313.044^{* *} \\
(-2.330)\end{array}$ & \begin{tabular}{r|}
$267.275^{* * *}$ \\
$(2.773)$
\end{tabular} & $\begin{array}{l}-45.697 \\
(-0.299)\end{array}$ & $\begin{array}{r}-254.827^{*} \\
(-1.924)\end{array}$ & $\begin{array}{r}-339.432^{* *} \\
(-2.190)\end{array}$ & $\begin{array}{r}-313.840 * * \\
(-2.572)\end{array}$ & $\begin{array}{r}-479.277^{* * *} \\
(-3.251)\end{array}$ & $\begin{array}{r}102.248 \\
(1.511)\end{array}$ \\
\hline Controls & Yes & Yes & Yes & Yes & Yes & Yes & Yes & Yes & Yes & Yes & Yes & Yes \\
\hline Two-way FE & Yes & Yes & Yes & Yes & Yes & Yes & Yes & Yes & Yes & Yes & Yes & Yes \\
\hline Adj. R2 & 0.83 & 0.84 & 0.42 & $0.33:$ & 0.38 & 0.30 & 0.91 & 0.28 & 0.27 & 0.27 & 0.32 & 0.14 \\
\hline Obs. & 832 & 832 & 832 & 832 & 832 & 832 & 832 & 572 & 572 & 572 & 572 & 572 \\
\hline Wald test: FE & $298^{* * *}$ & $1.163^{* * *}$ & 386*** & 25*** & $46^{* * *}$ & $1235^{* * *}$ & $1328^{* * *}$ & $78^{* * *}$ & $23^{* * *}$ & $103^{* * *}$ & $133^{* * *}$ & $88^{* * *}$ \\
\hline
\end{tabular}

Refer to Table 3. Alternatively calculated p-values are not reported as their additional explanatory power has been low in previous regressions.

Table 7 Fiscal Shocks and Debt Brakes, various periods

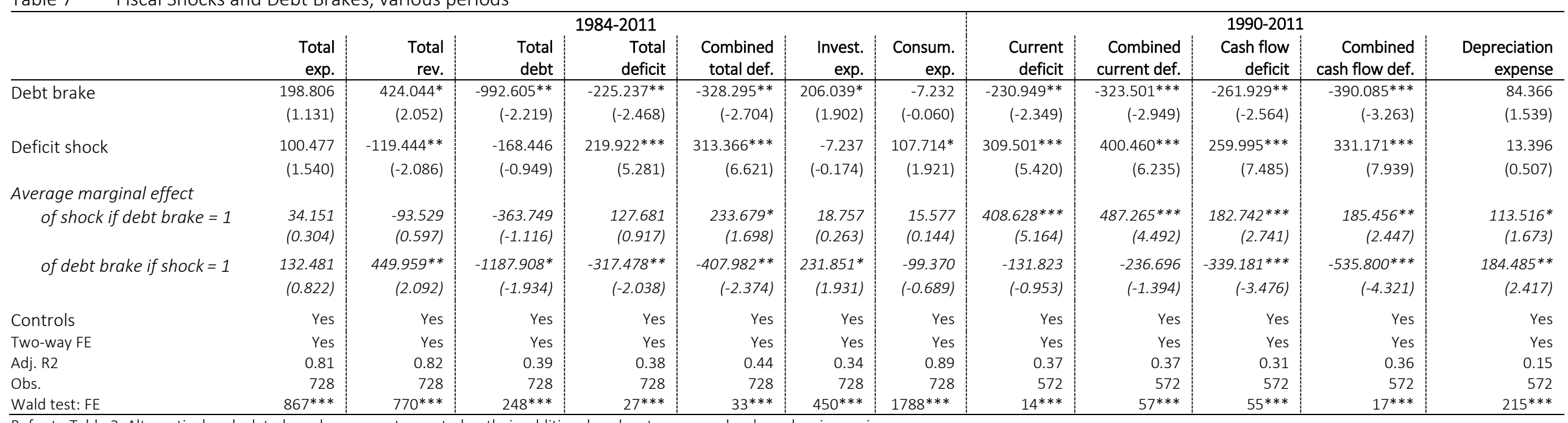

Refer to Table 3. Alternatively calculated p-values are not reported as their additional explanatory power has been low in previous 


\subsection{Fiscal Shocks}

To investigate the effects of fiscal rules in times of crisis, we interact the debt brake dummy with a binary indicator that equals one in case of a deficit shock and zero otherwise (Table 7). As expected, the results conclusively suggest that deficit shocks are associated with a deterioration of cantonal finances. This impact is almost equally composed of decreased revenue and increased consumption spending. The marginal effects of the interaction term indicate that cantonal debt brakes, which are particularly effective in times of crisis, mitigate the fiscal deterioration. To be precise, we find that the shock-induced decrease in revenue and the shock-induced increase in consumption spending and deficits are smaller in cantons with a debt brake than in other cantons.

Interestingly, the shock-induced increase in current deficit is not mitigated but intensified by cantonal debt brakes. While this result seems contrary to our above findings, it is plausible after careful investigation. As current deficit equals the cash flow deficit plus non-cash transactions, the latter are likely to be responsible for the opposite effect. In fact, we find depreciations, i.e., non-cash expenses, to significantly increase in years of deficit shocks if a debt brake is present. This increase is possibly due to fiscal rules requiring a depreciation of budget deficits.

In sum, we conclude that fiscal rules can dampen fiscal deterioration during unexpected deficit shocks by more rapid fiscal adjustments. As the fiscal impact of deficit shocks is not nullified but weakened, concerns that debt brakes are inflexible and immediately force harsh spending cuts or tax rises, fully offsetting fiscal shocks, are invalidated.

\section{Robustness Checks}

In the interest of clarity, the subsequent robustness tests focus primarily on the direct effect of cantonal debt brakes. The role of elections and fiscal shocks are not double-checked and evasive reactions are only briefly addressed. Our baseline findings are summarized in Table 8 (column I). As cantonal data is often subject to outlier concerns, we exclude the cantons BaselCity and Geneva (column II). In addition, we use median regression (0.5 quantile) which is more robust to outlying observations (column III). A further robustness test replaces the debt brake dummy with an index that measures the stringency of cantonal debt brakes (column IV). Moreover, we trim our data to the sub-period 1990-2011 in order to account for a major revision in accounting standards (column V). A next robustness check replaces time fixed effects by a time trend (column VI). Finally, we exclude cantonal fixed effects as previous studies, with 
considerably less institutional variation, assuming that fixed effects mask the impact of cantonal debt brakes and render them insignificant (column VII).

Table 8 Summary of the Robustness Checks

\begin{tabular}{|c|c|c|c|c|c|c|c|c|}
\hline & & 1 & II & III & IV & V & $\mathrm{VI}$ & VII \\
\hline & Dependent variable & $\begin{array}{l}\text { Baseline } \\
\text { finding }\end{array}$ & $\begin{array}{l}\text { Cantons } \\
\text { excluded }\end{array}$ & $\begin{array}{l}\text { Median } \\
\text { regression }\end{array}$ & $\begin{array}{l}\text { Stringency } \\
\text { index }\end{array}$ & $\begin{array}{l}\text { Sub-period } \\
1990-2011 \\
\end{array}$ & Time trend & $\begin{array}{l}\text { No canton } \\
\text { fixed effects }\end{array}$ \\
\hline \multirow{8}{*}{$\begin{array}{l}1980 \text { - } \\
2011 \\
\text { (except } \\
\text { V) }\end{array}$} & Total expenditure & $\uparrow$ & confirm & confirm & confirm & confirm & confirm & confirm \\
\hline & Total revenue & $\uparrow(5 \%)$ & confirm & ! not* & ! not* & confirm & confirm & ! not* \\
\hline & Total debt & $\downarrow \quad(5 \%)$ & confirm & confirm & ! not* & confirm & confirm & ! not* \\
\hline & Total deficit & $\downarrow \quad(5 \%)$ & confirm & confirm & confirm & confirm & confirm & confirm \\
\hline & Comb. total deficit & $\downarrow \quad(5 \%)$ & confirm & confirm & confirm & confirm & confirm & confirm \\
\hline & Invest. expenditure & $\uparrow(5 \%)$ & confirm & confirm & confirm & ! not* & ! not* & $!+/-$ not $*$ \\
\hline & Consum. exp. & $\downarrow$ & confirm & $+/-$ & confirm & confirm & $+/-$ & $+/-$ \\
\hline & Investment ratio & $\uparrow(10 \%)$ & confirm & ! not* & confirm & ! not* & ! not* & $!+/-$ not $*$ \\
\hline \multirow{5}{*}{$\begin{array}{l}1990- \\
2011\end{array}$} & Current deficit & $\downarrow(10 \%)$ & ! not* & confirm & confirm & confirm & confirm & ! not* \\
\hline & Comb. current def. & $\downarrow \quad(5 \%)$ & confirm & confirm & confirm & confirm & confirm & ! not* \\
\hline & Cash flow deficit & $\downarrow \quad(5 \%)$ & confirm & confirm & confirm & confirm & confirm & confirm \\
\hline & Comb. cash flow def. & $\downarrow \quad(1 \%)$ & confirm & confirm & confirm & confirm & confirm & confirm \\
\hline & Depreciation exp. & $\uparrow(10 \%)$ & confirm & confirm & confirm & confirm & confirm & ! not* \\
\hline
\end{tabular}

$\downarrow$ or $\uparrow$ indicates a negative or positive effect of cantonal debt brakes on the dependent variable in the baseline regression. In parentheses are the corresponding levels of significance. "confirm" means that the estimated sign of the debt brake and its insignificance or significance (at any conventional level of $1 \%, 5 \%$ or $10 \%$ ) is confirmed by the robustness test. "! not *" means that the debt brake obtains significance in the baseline regression but not in the robustness check. "! +/" indicates a different sign in the robustness test than in the baseline estimation. The robustness regressions include all controls as in the baseline model and two-way fixed effects (not in VI and VII). The findings are based on cantonal clustered standard errors. Full regression bodies available upon request.

The robustness tests largely confirm our baseline findings, i.e., cantonal fiscal rules can be associated with significantly decreased debt and deficits. The highly significant negative impact of cantonal fiscal rules on the most narrowly defined budget variable, i.e., cantonal cash flow, continues to exist in all tests. Contrary to our baseline results, several robustness tests suggest that the debt brake-related increases in total revenue, investment expenditure and investment ratio are not statistically significant. Therefore, some doubts remain as to the evidence that debt brakes lead to an expansion of investment spending.

It is hardly surprising that our results are most sensitive to the exclusion of fixed effects as this test constitutes a deviation from our underlying identification strategy, i.e., difference-indifferences. In addition, the debt brake dummy varies widely making the exclusion of fixed effects problematic: On the one hand, the issue of omitted variables arises. On the other hand, unobserved cantonal asymmetries are not adequately taken into account. Moreover, fixed effects seem necessary to mitigate the impact of block concentrated outliers and to control for voters' preferences. This is supported by Wald tests as they suggest including two-way fixed effects (see previous regression tables). Still, an exclusion of fixed effects does not substantially change our conclusion, i.e., cantonal debt brakes support sound finances. 


\section{Conclusion}

The paper presents a wide-ranging investigation of the effects of Swiss cantonal debt brakes on cantonal finances alongside currently unanswered questions relating to evasive reactions, political budget cycles and fiscal shocks. By taking the legal coverage of fiscal rules into account and analyzing various budget components, we differentiate between direct effects of fiscal rules on the targeted variable and unintended indirect effects (e.g., evasive measures).

In line with the empirical literature, a difference-in-differences approach reveals conclusive evidence that cantonal debt brakes are associated with sound finances at the cantonal and municipal level of government. We are among the first to show that this effect is stronger, the better the analyzed budget position corresponds with the variable targeted by the rule. The differentiated effect on different deficit variables emphasize the importance to distinguish between direct and indirect effects of fiscal rules. In addition, evidence rejects the common claim that cantonal debt brakes hurt public investments.

Since cantonal debt brakes put much stronger constraints on the current budget than on the investment budget - if the latter is restricted at all - we examine whether politicians evade their debt brake by flying into the investment budget. While we find little evidence for such unintended effects, the results uncover the importance of implementing fiscal rules that legally cover all accounts. Similarly, an evasion into funds and special financing is rejected, too.

Given that cantonal debt brakes effectively constrain cantonal fiscal policy, the question is raised whether the rules also restrict political budget cycles and the responsiveness of cantonal budgets to fiscal shocks. As expected, we find that cantonal finances deteriorate in years of government election and during deficit shocks. However, the paper provides evidence that cantonal debt brakes can mitigate political budget cycles and the impact of deficit shocks. As the fiscal impact of deficit shocks is not completely offset by cantonal debt brakes, concerns that the rules are inflexible and immediately force harsh budgetary adjustments are invalidated. 


\section{References}

Alesina, A. and T. Bayoumi (1996), "The Costs and Benefits of Fiscal Rules: Evidence from U.S. States", National Bureau of Economic Research Working Paper 5614.

Alesina, A. and A. Passalacqua (2015), "The Political Economy of Government Debt, in: J. Taylor and H. Uhlig, eds., Handbook of Macroeconomics, in preparation, NBER Working Paper 21821.

Alesina, A., R. Hausmann, R. Hommes and E. Stein (1999), "Budget Institutions and Fiscal Performance in Latin America", Journal of Development Economics 59, 253-273.

Alt, J.E. and R.C. Lowry (1994), "Divided Government, Fiscal Institutions, and Budget Deficits: Evidence from the States", American Political Science Review 88, 811-828.

Alt, J.E. and S.S. Rose (2007), "Context-Conditional Political Budget Cycles", in C. Boix and S.C. Stokes, eds., The Oxford Handbook of Comparative Politics, Oxford University Press, Oxford, 845-867.

Alt, J.E., D.D. Lassen and J. Wehner (2014), "It Isn't Just about Greece: Domestic Politics, Transparency and Fiscal Gimmickry in Europe", British Journal of Political Science 44, 707-716.

Ayuso-i-Casals, J., D.G. Hernandez, L. Moulin and A. Turrini (2007), "Beyond the SGP: Features and Effects of EU National-Level Fiscal Rules", in: J. Ayuso-i-Casals, S. Deroose, E. Flores and L. Moulin, eds., The Role of Fiscal Rules and Institutions in Shaping Budgetary Outcomes, European Commission Economic Papers 275, 191242.

Bayoumi, T. and B. Eichengreen (1995), "Restraining Yourself: The Implications of Fiscal Rules for Economic Stabilization", IMF Staff Papers 42, 32-48.

Beetsma, R., M. Giuliodori and P. Wierts (2009), "Planning to Cheat: EU Fiscal Policy in Real Time", Economic Policy 24, 753-804.

Benito, B., F. Bastida and C. Vicente (2013), "Creating Room for Manoeuvre: a Strategy to Generate Political Budget Cycles under Fiscal Rules", Kyklos 66, 467-496.

Blume, L. and S. Voigt (2013), "The Economic Effects of Constitutional Budget Institutions", European Journal of Political Economy 29, 236-251.

Brambor, T., W.R. Clark and M. Golder (2006), "Understanding Interaction Models: Improving Empirical Analyses", Political Analysis 14, 63-82.

Bunch, B.S. (1991), "The Effect of Constitutional Debt Limits on State Governments' Use of Public Authorities", Public Choice 68, 57-69.

Bundesrat (2013), "Die Schuldenbremse des Bundes: Erfahrungen und Perspektiven", Schweizer Eidgenossenschaft, Bern.

Burret, H.T. and L.P. Feld (2014a), "A Note on Budget Rules and Fiscal Federalism”, CESifo DICE Report 1, 3-11.

Burret, H.T. and L.P. Feld (2014b), "Vertical Effects of Fiscal Rules - The Swiss Experience", CESifo Working Paper 5043.

Buti, M. and P. Van den Noord (2004), "Fiscal Discretion and Elections in the Early Years of EMU", Journal of Common Market Studies 39, 737-756.

Buti, M., J.M. Martins and A. Turrini (2007), "From Deficits to Debt and Back: Political Incentives under Numerical Fiscal Rules", CESifo Economic Studies 53, 115-152.

Cameron, A.C. and D.L. Miller (2015), "A Practitioner's Guide to Cluster-Robust Inference", Journal of Human Resources 50, 317-372.

Cameron, A.C., J.B. Gelbach and D.L. Miller (2008), "Bootstrap-based Improvements for Inference with Clustered Errors", Review of Economics and Statistics 90, 414-427.

Cameron, A.C., J.B. Gelbach and D.L. Miller (2011), "Robust Inference with Multiway Clustering", Journal of Business \& Economic Statistics 29, 238-249.

Chaney, B.A., P.A. Copley and M.S. Stone (2002), "The Effect of Fiscal Stress and Balanced Budget Requirements on the Funding and Measurement of State Pension Obligations", Journal of Accounting and Public Policy 21, 287-313.

Clémenceau, M. (2014), “Creative Accounting: A Process for Finance Ministers to Influence Governments' Financial Performance. Evidence from Swiss Cantons", Doctoral Thesis, University of Lausanne.

Clémenceau, M and N. Soguel (2014), "Impacts des Imputations Internes sur le Niveau des Déficits Publics: Le Cas des Cantons Suisses", in: M. Djouldem, G. Tellier and C. de Visscher, eds., Les Réformes des Finances Publiques, Bruylant, Bruxelles, 187-213. 
Conference of Cantonal Ministers of Finance (2012), "Finanzpolitische Regeln der Kantone: Ausgaben-, Defizitund Schuldenbremsen zum Stand: 18. December 2012", downloadable from: http://www.fdkcdf.ch/121218_hh-regeln_update_def_d.pdf.

Conference of Cantonal Ministers of Finance (2013), "Handbook on the Harmonized Accounting Model for the Cantons and Communes (HAM2)", Solothurn.

Costello, A.M., R. Petacchi and J. Weber (2014), "Consequences of State Balanced Budget Restrictions: Fiscal Constraints or Accounting Manipulations?", downloadable from: http://ssrn.com/abstract=2151598.

Dafflon, B. and F. Pujol (2001), "Fiscal Preferences and Fiscal Performance: Swiss Cantonal Evidence”, International Public Management Review 2, 54-76.

De Haan, J. and J.-E. Sturm (1994), "Political and Institutional Determinants of Fiscal Policy in the European Community", Public Choice 80, 157-172.

De Haan, J., W. Moessen and B. Volkerink (1999), "Budgetary Procedures: Aspects and Changes: New Evidence for some European countries", in: J.M. Poterba and J. von Hagen, eds., Fiscal Institutions and Fiscal Performance, University of Chicago Press, Chicago, 265-300.

Debrun, X., L. Moulin, A. Turrini, J. Ayuso-i-Casals and M.S. Kumar (2008), "Tied to the Mast? National Fiscal Rules in the European Union", Economic Policy 23, 297-362.

Drazen, A. (2000), "The Political Business Cycle after 25 Years", NBER Macroeconomics Annual 2000, MIT Press, Cambridge MA.

Ebeke, C. and D. Ölçer (2013), "Fiscal Policy Over the Election Cycle in Low-Income Countries", IMF Working Paper 13/153.

Eichengreen, B. and T. Bayoumi (1994), "The Political Economy of Fiscal Restrictions: Implications for Europe from the United States", European Economic Review 38, 783-791.

Fatás, A. and I. Mihov (2006), "The Macroeconomic Effects of Fiscal Rules in the US states", Journal of Public Economics 9, 101-117.

Feld, L.P. (2000), "Tax Competition and Income Redistribution: An Empirical Analysis for Switzerland", Public Choice 105, 125-164.

Feld, L.P. and G. Kirchgässner (2001a), "The Political Economy of Direct Legislation: Direct Democracy and Local Decision-Making", Economic Policy 16, 329-367.

Feld, L.P. and G. Kirchgässner (2001b), “Does Direct Democracy Reduce Public Debt? Evidence from Swiss Municipalities", Public Choice 109, 347-370.

Feld, L.P. and G. Kirchgässner (2001c), "Income Tax Competition at the State and Local Level in Switzerland", Regional Science and Urban Economics 31, 181-213.

Feld, L.P. and G. Kirchgässner (2003), "The Impact of Corporate and Personal Income Taxes on the Location of Firms and on Employment: Some Panel Evidence for the Swiss Cantons", Journal of Public Economics 87, 129-155.

Feld, L.P. and G. Kirchgässner (2004), "Sustainable Fiscal Policy in a Federal System: Switzerland as an Example", in: H. Kriesi, P. Farago, M. Kohli and M. Zarin-Nejadan (eds.), Contemporary Switzerland: Revisiting the Special Case, Palgrave Macmillan, Basingstoke, 281-296.

Feld, L.P. and G. Kirchgässner (2008), "On the Effectiveness of Debt Brakes: The Swiss Experience”, in: R. Neck and J.-E. Sturm, eds., Sustainability of Public Debt, MIT Press, Cambridge MA and London, 223-255.

Feld, L.P. and J.G. Matsusaka (2003), "Budget Referendums and Government Spending: Evidence from Swiss Cantons", Journal of Public Economics 87, 611-645.

Feld, L.P. und E. Reulier (2009), "Strategic Tax Competition in Switzerland: Evidence from a Panel of the Swiss Cantons", German Economic Review 10, 91-114.

Feld, L.P., G. Kirchgässner and C.A. Schaltegger (2010), "Decentralized Taxation and the Size of Government: Evidence from Swiss State and Local Governments", Southern Economic Journal 77, 27-48.

Feld, L.P., C.A. Schaltegger and J. Schnellenbach (2008), "On Government Centralization and Fiscal Referendums", European Economic Review 52, 611-645.

Feld, L.P., A. Kalb, M.-D. Moessinger and S. Osterloh (2013), "Sovereign Bond Market Reactions to Fiscal Rules and No-bailout Clauses: The Swiss Experience", CESifo Working Paper 4195.

Foremny, D. (2014), "Sub-national Deficits in European Countries: The Impact of Fiscal Rules and Tax Autonomy", European Journal of Political Economy 34, 86-110.

Frankel, J. (2011), "Over-optimism in Forecasts by Official Budget Agencies and Its Implications", Oxford Review of Economic Policy 27, 536-562. 
Frankel, J. and J. Schreger (2013), "Over-optimistic Official Forecasts and Fiscal Rules in the Eurozone", Review of World Economy 149, 147-272.

Funk, P. and C. Gathmann (2011), "Does Direct Democracy Reduce the Size of Government? New Evidence from Historical Data: 1890-2000", Economic Journal 121, 1252-1280.

Galletta, S. and M. Jametti (2015), "How to Tame two Leviathans? Revisiting the Effect of Direct Democracy on Local Public Expenditure in a Federation", European Journal of Political Economy 39, 82-93.

Gollwitzer, S. (2010), "Budget Institutions and Fiscal Performance in Africa", Journal of African Economies 20, 111152.

Grembi, V., T. Nannicini and U. Troiano (2012), "Policy Responses to Fiscal Restraints: A Difference-indiscontinuities Design", IZA Institute for the Study of Labor Discussion Papers 6952, Bonn.

Guichard, S., M. Kennedy, E. Wurzel and C. André (2007), "What Promotes Fiscal Consolidation: OECD Country Experiences", OECD Economics Departments Working Paper 553.

Hallerberg, M., R. Strauch and J. von Hagen (2007), "The Design of Fiscal Rules and Forms of Governance in European Union Countries", European Journal of Political Economy 23, 338-359.

Heinemann, F., M.-D. Moessinger and M. Yeter (2016): "Do Fiscal Rules Constrain Fiscal Policy? A Meta-RegressionAnalysis", Centre for European Economic Research (ZEW) Discussion Paper 16-027.

Holm-Hadulla, F., S. Hauptmeier and P. Rother (2012), "The Impact of Expenditure Rules on Budgetary Discipline over the Cycle", Applied Economics 44, 3287-3296.

Hou, Y. and D.L. Smith (2010), "Do State Balanced Budget Requirements Matter? Testing Two Explanatory Frameworks", Public Choice 145, 57-79.

Imbeau, L.M. and G. Tellier (2004), "The Political-Economy of Budget Deficits in the Canadian Provinces, 19682000", in: L.M. Imbeau and F. Pétry, eds., Politics, Institutions, and Fiscal Policy: Deficits and Surpluses in Federated States, Lexington Books, Lanham, 89-111.

Kiewiet, D.R. and K. Szakaly (1996), "Constitutional Limitations on Borrowing: An Analysis of State Bonded Indebtedness", Journal of Law, Economics \& Organization 12, 62-97.

Klomp, J. and J. de Haan (2013), "Political budget Cycles and Election Outcomes", Public Choice 157, $245-267$.

Koen, V. and P. van den Noord (2005), "Fiscal Gimmickry in Europe: One-Off Measures and Creative Accounting", OECD Economics Department Working Papers 417.

Krishnakumar, J., M.-J. Martin and N. Soguel (2010), "Explaining Fiscal Balances with a Simultaneous Equation Model of Revenue and Expenditure: A Case Study of Swiss Cantons Using Panel Data", Public Budgeting \& Finance 30, 69-94.

Krogstrup, S. and S. Wälti (2008), “Do Fiscal Rules Cause Budgetary Outcomes?”, Public Choice 136, $123-138$.

Krol, R. and S. Svorny (2007), "Budget Rules and State Business Cycles", Public Finance Review 35, 530-544.

Lavigne, R. (2011), "The Political and Institutional Determinants of Fiscal Adjustment: Entering and Exiting Fiscal Distress", European Journal of Political Economy 27, 17-35.

Levinson, A. (1998), "Balanced Budget and Business Cycles: Evidence from the States", National Tax Journal 41, 715-732.

Levinson, A. (2007), "Budget Rules and State Business Cycles: A Comment”, Public Finance Review 35, 545-549.

Luechinger, S. and C.A. Schaltegger (2013), "Fiscal Rules, Budget Deficits and Budget Projections", International Tax and Public Finance 20, 785-805.

MacKinnon, J. and M. Webb (2015), "Wild Bootstrap Inference for Wildly Different Cluster Sizes", Queen's University Department of Economics Working Paper 1314.

Mahdavi, S. and J. Westerlund, (2011), "Fiscal Stringency and Fiscal Sustainability: Panel Evidence from the American State and Local Governments", Journal of Policy Modelling 33, 953-969.

Malde, B. (2012), "Bootwildct: Ado file for Stata", Economic and Social Research Council.

Marneffe, W., B. Van Aarle, W. Van der Wielen and L. Vereeck (2011), "The Impact of Fiscal Rules on Public Finances in the Euro Area", CESifo DICE Report 3, 18-25.

Martin, M.-J. and N. Soguel (2004), "Towards a Model for Predicting Deficits and Surpluses in Swiss Cantons" in: L.M. Imbeau and F. Pétry, eds., Politics, Institutions, and Fiscal Policy : Deficits and Surpluses in Federated States, Lexington, Lanham, 135-159.

Matsusaka, J.G. (1995), "Fiscal Effects of the Voter Initiative: Evidence from the Last 30 Years", Journal of Political Economy 103, 587-623.

Milesi-Ferretti, G. and K. Moriyama (2006), "Fiscal Adjustment in EU Countries: A Balance Sheet Approach", Journal of Banking \& Finance 30, 3281-3298. 
Mitchell, W.E. (1967), "The Effectiveness of Debt Limits on State and Local Government Borrowing", The Bulletin 45, New York University Institute of Finance, New York.

Nice, D.C. (1991), "The Impact of State Policies to Limit Debt Financing", Publius 21, 69-82.

Nordhaus, W.D. (1975), "The Political Business Cycle", Review of Economic Studies 42, 169-190.

Pétry, F. (2004), "Deficits and Surpluses in Federated States: A Pooled Analysis", in: L.M. Imbeau and F. Pétry, eds., Politics, Institutions, and Fiscal Policy: Deficits and Surpluses in Federated States, Lexington, Lanham, 203224.

Pina, A.M. and N.M Venes (2011), "The Political Economy of EDP Fiscal Forecasts: An Empirical Assessment", European Journal of Political Economy 27, 534-546.

Pogue, T.F. (1970), "The Effect of Debt Limits: Some New Evidence", National Tax Journal 23, 36-49.

Poterba, J.M. (1994), "State Response to Fiscal Crises: The Effects of Budgetary Institutions and Politics", Journal of Political Economy 102, 799-821.

Poterba, J.M. (1996), "Budget Institutions and Fiscal Policy in the U.S. States", American Economic Review 86, 395400.

Poterba, J.M. and K.S. Rueben (1999), "Fiscal Rules and State Borrowing Costs: Evidence from California and Other States", Public Policy Institute of California, San Francisco.

Poterba, J.M. and K.S. Rueben (2001), "Fiscal News, State Budget Rules, and Tax-Exempt Bond Yields", Journal of Urban Economics 50, 537-562.

Primo, D.M. (2006), "Stop Us Before We Spend Again: Institutional Constraints on Government Spending", Economics \& Politics 18, 269-312.

Rose, S.S. (2006), "Do Fiscal Rules Dampen the Political Business Cycle”, Public Choice 128, 407-431.

Roubini, N. and J.D. Sachs (1989a), "Political and Economic Determinants of Budget Deficits in the Industrial Democracies", European Economic Review 33, 903-938.

Roubini, N. and J.D. Sachs (1989b), "Government Spending and Budget Deficits in the Industrial Countries", Economic Policy 8, 99-132.

Schaltegger, C.A. (2002), "Budgetregeln und ihre Wirkung auf die öffentlichen Haushalte: Empirische Ergebnisse aus den US-Bundesstaaten und den Schweizer Kantonen“, Schmollers Jahrbuch 122, 369-413.

Schaltegger, C.A. and L.P. Feld (2009a), "Do Large Cabinets Favor Large Governments? Evidence on the Fiscal Commons Problem for Swiss Cantons", Journal of Public Economics 93, 35-47.

Shadbegian, R.J. (1996), "Do Tax and Expenditure Limitations Affect the Size and Growth of State Government?", Contemporary Economic Policy 14, 22-35.

Singh, R. and A. Plekhanov (2006), "How Should Subnational Government Borrowing be Regulated? Some CrossCountry Empirical Evidence", IMF Staff Papers 53, 426-452.

Sørensen, B.E., L. Wu and O. Yosha (2001), "Output Fluctuations and Fiscal Policy: U.S. State and Local Governments 1978-1994", European Economic Review 45, 1271-1310.

Stauffer, T.P. (2001), "Instrumente des Haushaltsausgleichs: Ökonomische Analyse und rechtliche Umsetzung", Helbing und Lichtenhahn, Basel.

Strauch, R.R. (1999), Budgetprozesse und Haushaltsdisziplin - Eine Analyse der US-Amerikanischen Staaten, Dissertation an der Rechts- und Staatswissenschaftlichen Fakultät der Rheinischen Friedrich-WilhelmsUniversität Bonn, University of Bonn.

Tapp, S. (2013), "The Use and Effectiveness of Fiscal Rules in Canadian Provinces", Canadian Public Policy 39, 4570.

Von Hagen, J. (1991), "A Note on the Empirical Effectiveness of Formal Fiscal Restraints", Journal of Public Economics 44, 199-210.

Von Hagen, J. (1992), "Fiscal Arrangements in a Monetary Union: Evidence from the U.S.", in: D.E. Fair and C. de Boissieu, eds., Fiscal Policy, Taxation and the Financial System in an Increasingly Integrated Europe, Kluwer Academic Publishers, Dordrecht, 337-360.

Von Hagen, J. and G.B. Wolff (2006), "What do Deficits tell us About Debt? Empirical Evidence on Creative Accounting with Fiscal Rules in the EU", Journal of Banking \& Finance 30, 3259-3279.

Waldmeier, D. and B. Mäder (2015), Handbuch der Schuldenbremsen der Schweiz - Regeln der Insolvenzvorsorge im Zusammenspiel mit dem geltenden Haushaltsrecht, ed. by C.A. Schaltegger, K.A. Vallender and T. Angelini, Haupt, Bern

Yerly, N. (2013), "The Political Economy of Budget Rules in the Twenty-six Swiss Cantons: Institutional Analysis, Preferences and Performance", Ph.D. Thesis, University of Fribourg. 


\section{Appendix}

Table A.1 Summary of Fiscal Rules in the Swiss Cantons

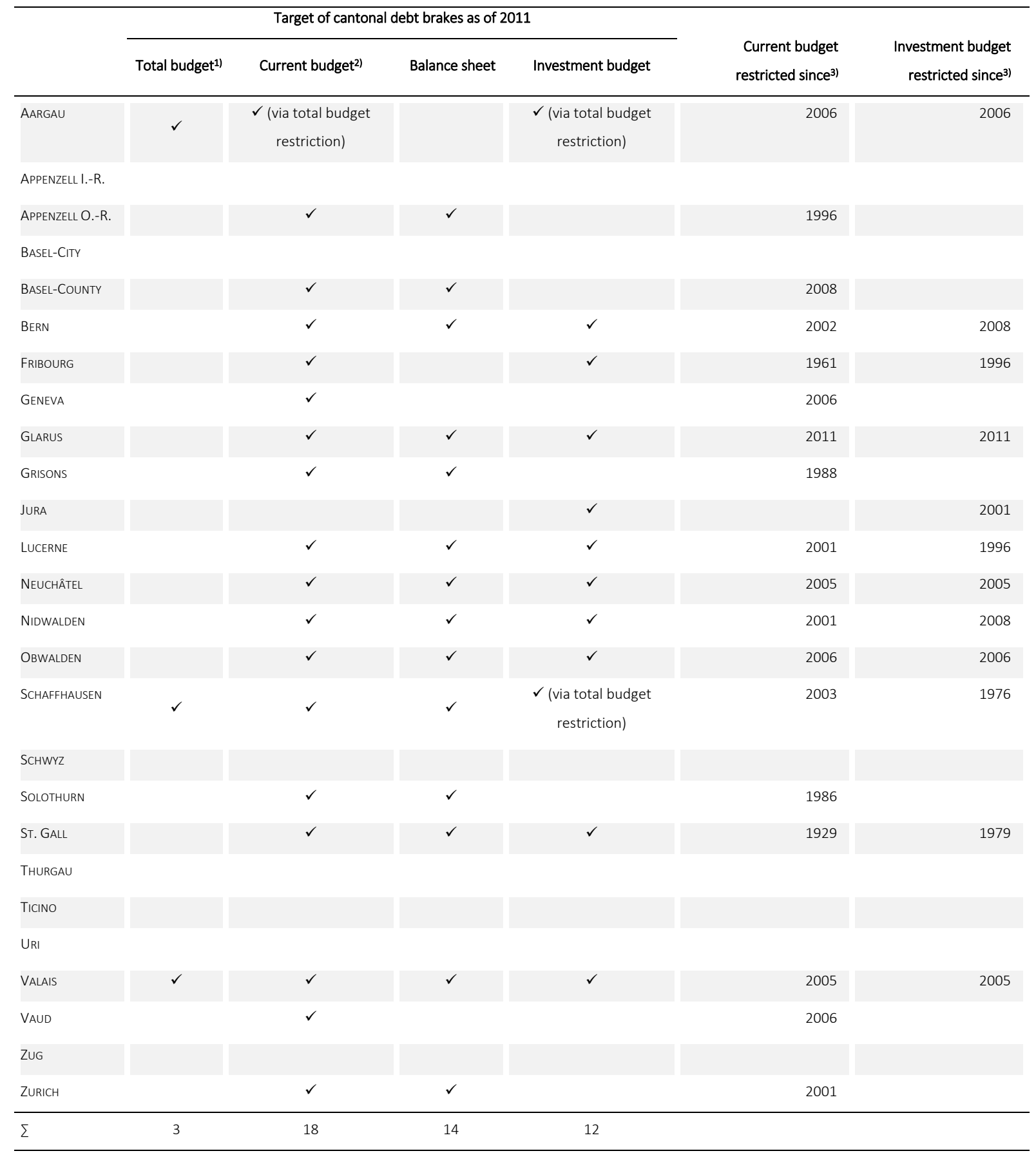

1) Refers to the legal terms "Finanzrechnung", "Finanzierungsrechnung", "Finanzhaushalt", "Verwaltungsrechnung", "gestion financière" and "gestione finanziaria". 2) Refers to the legal terms "Erfolgsrechnung", "laufende Rechnung", "Aufwandsüberschussrechnung", "budget de fonctionnement", "conto economico" and "gestione corrente". 3) The year indicates the year in which the debt brake (investment constraint) has first been introduced. If the rule was in force for less than six month in the year of original introduction the year following the introduction is indicated. Due to differences in personal interpretation, perception and knowledge of cantonal laws, practices and court decisions cantonal rules might be classified differently by other studies. Our classification is based on extensive legal research and was sent to the cantonal Departments of Finances for verification. A broad overview of cantonal budget rules is provided by Stauffer (2001) and more recently by Conference of Cantonal Ministers of Finance (2012) and Waldmeier and Mäder (2015) 
Figure A.1

Cantonal Accounting

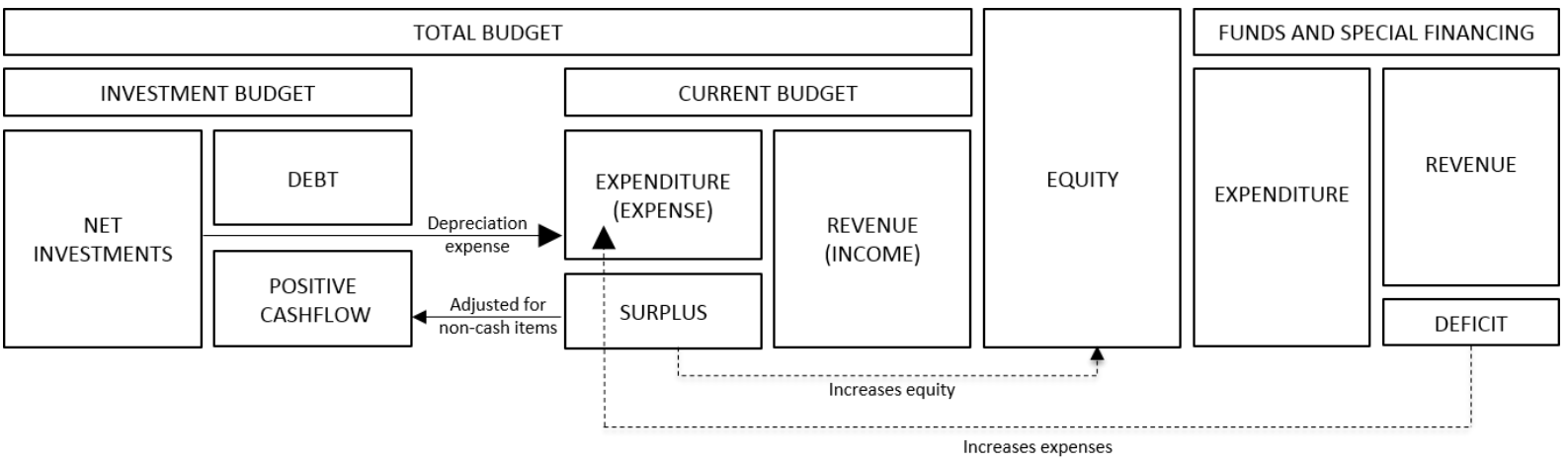

Source: Own illustration.

Figure A.2 Cantonal Budget Deficits and Deficit Shocks by Year and Canton
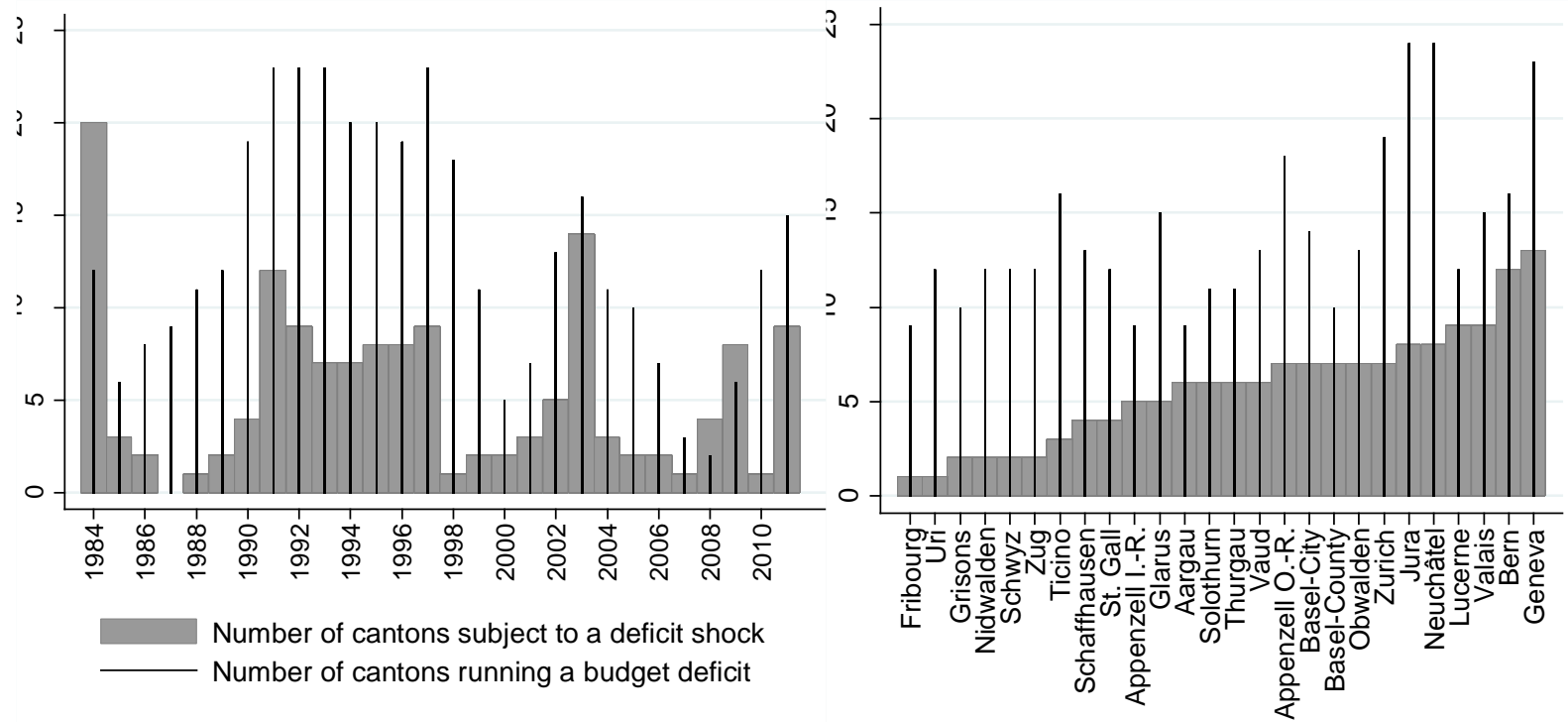

Number of cantons subject to a deficit shock

Number of cantons running a budget deficit

Number of years with deficit shock

Number of years with budget deficit

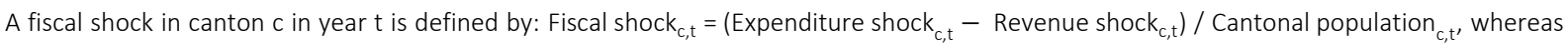
Expenditure shock $k_{c, t}=$ Actual current expenditure $_{c, t}-$ Forecasted current expenditure $_{t \mid c, t-1}$ and Revenue shock $k_{c t}=$ Actual current revenue $_{c, t}$ Forecasted current revenue $e_{t \mid c t-1}$. Thus, a positive (negative) fiscal shock indicates a deficit (surplus) shock. Furthermore, the definition of a fiscal shock implicitly assumes that the fiscal year's budget forecasts are not (strategically) biased. We use deficit shocks instead of budget deficits as the latter might not be unexpected but intentional. 
Figure A.3 Testing for Common Trends in Cantonal Finances

Real cantonal expenditure per capita

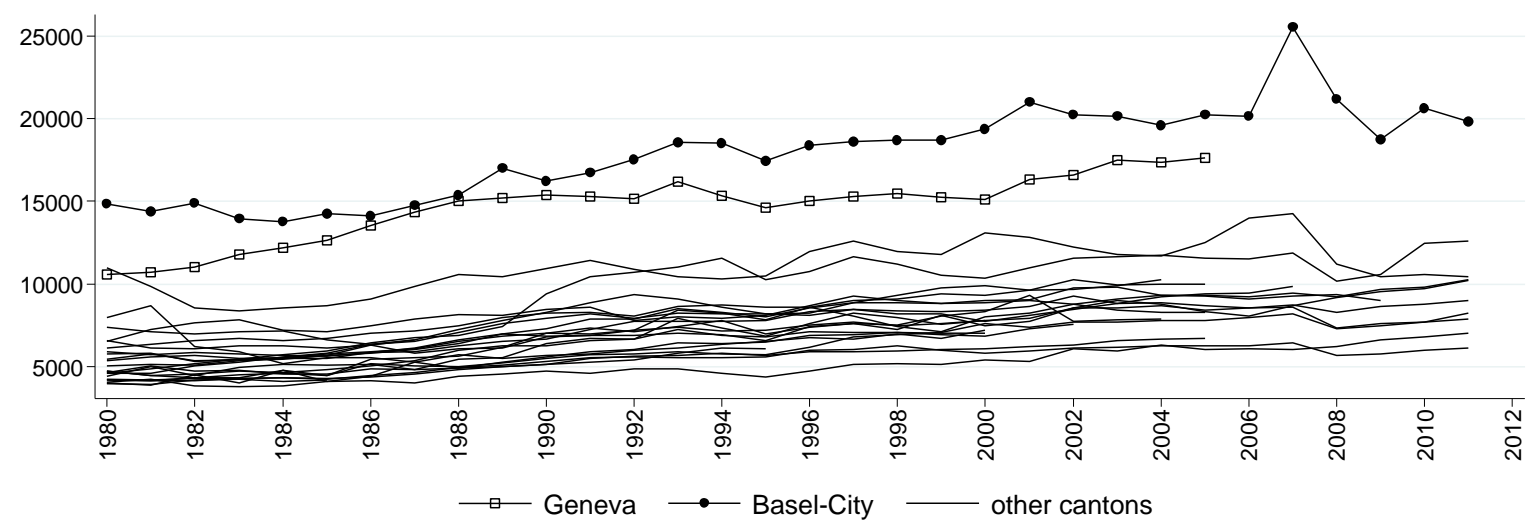

Real cantonal revenue per capita

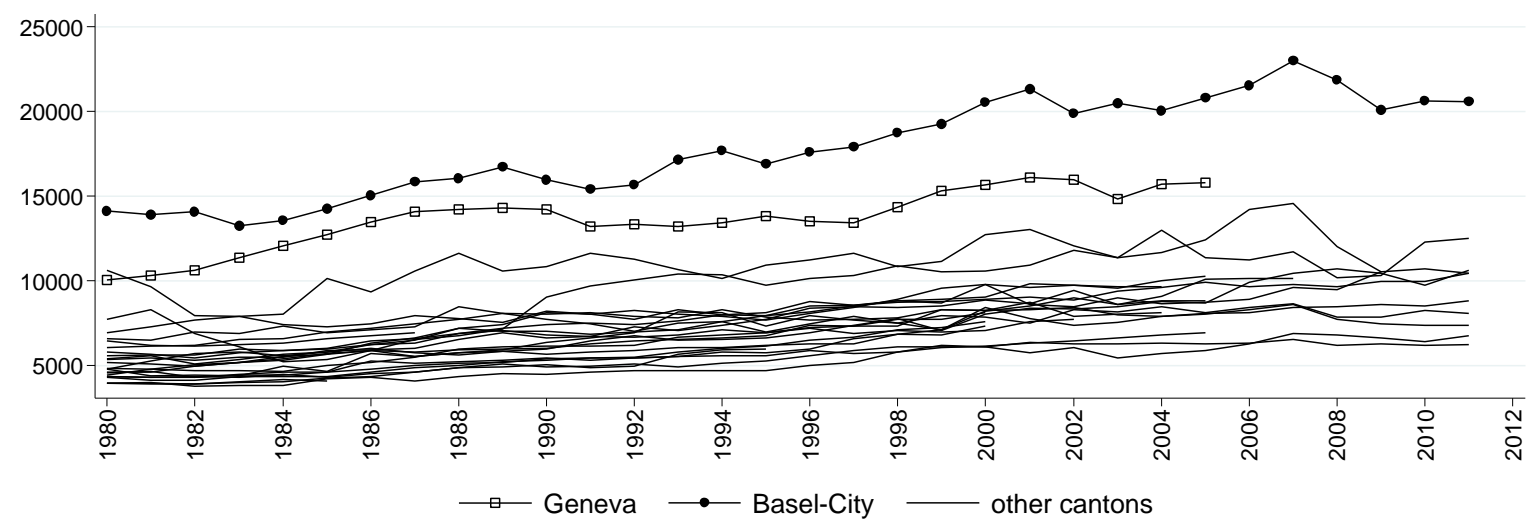

Real cantonal debt per capita

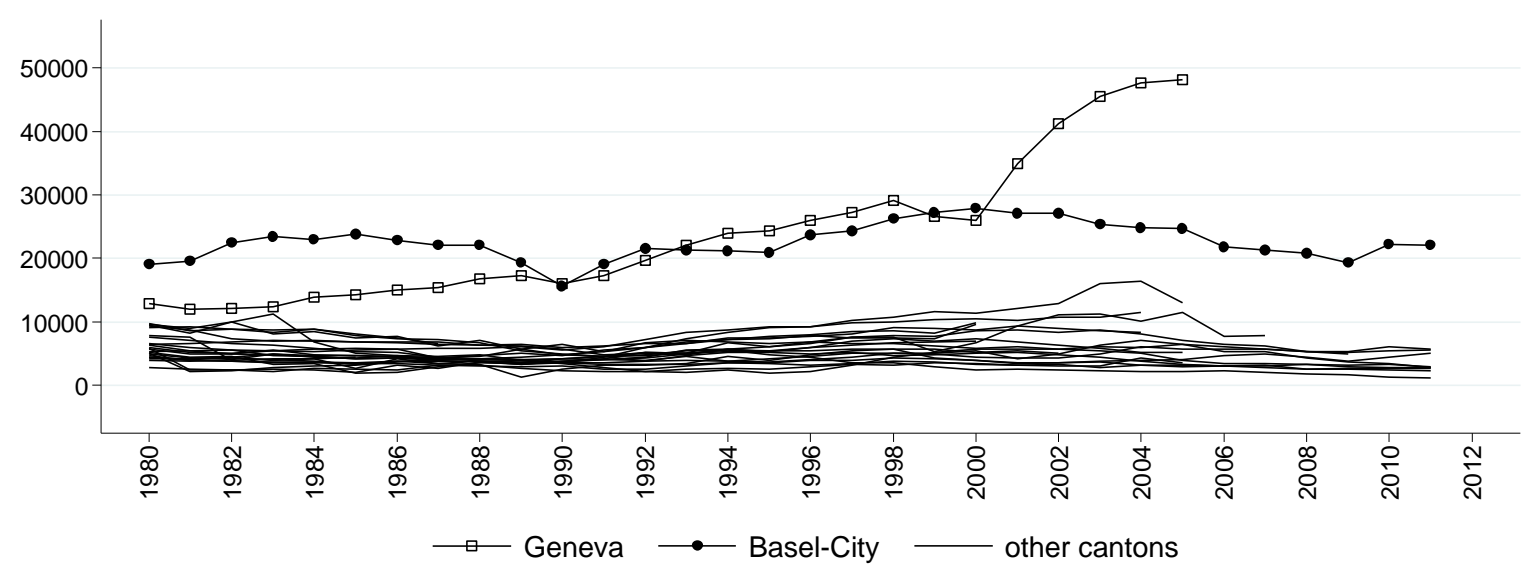

The graphs show the development of cantonal finances prior to the treatment, i.e. the introduction of a debt brake. Source: Own calculation based on data from Swiss Finance Administration. 
Table A.2 Definition and Source of Variables

\begin{tabular}{|c|c|}
\hline Variables & Source \\
\hline Total expenditure per capita & Swiss Finance Administratio \\
\hline Total revenue per capita & Swiss Finance Administratio \\
\hline Total debt per capita & Swiss Finance Administratio \\
\hline Total deficit per capita & Own calculation \\
\hline Combined total deficit per capita & Own calculation \\
\hline Investment spending per capita & Swiss Finance Administratic \\
\hline Consumption spending per capita & Own calculation \\
\hline Current spending per capita & Swiss Finance Administratio \\
\hline Cash flow deficit per capita & Own calculation \\
\hline Combined cash flow deficit per capita & Own calculation \\
\hline Current deficit per capita & Swiss Finance Administratic \\
\hline Combined current deficit per capita & Swiss Finance Administratic \\
\hline Depreciation expense per capita & Swiss Finance Administratio \\
\hline Investment ratio & Own calculation \\
\hline Debt brake dummy & Own research \\
\hline Debt brake stringency index & Own research \\
\hline Investment rule dummy & Own research \\
\hline Spending threshold & Own research \\
\hline Signature requirement for initiative & Own research \\
\hline Mandatory referenda dummy & Own research \\
\hline Unemployment rate & Swiss Statistical Office \\
\hline Taxable income per capita & Swiss Finance Administratio \\
\hline Relative income & Own calculation \\
\hline Federal aid per capita & Swiss Finance Administratio \\
\hline Population & Swiss Statistical Office \\
\hline Share old & Swiss Statistical Office \\
\hline Share young & Swiss Statistical Office \\
\hline Share German speaking & Swiss Statistical Office \\
\hline Ideology of parliament & Own calculation \\
\hline Election year & Swiss Statistical Office \\
\hline Deficit shock & Own calculation \\
\hline
\end{tabular}

Description

Includes extraordinary expenditure.

Includes extraordinary revenue.

For reasons of comparability we follow EFV staff recommendation and added the account "Other accrued expense and deferred income, statement of financial performance" (item 2049) from 1990 onwards.

$=$ Total spending - Total revenue.

= Total cantonal and local spending - Total cantonal and local revenue.

Includes extraordinary investment spending.

= Non-investment spending $=$ Total expenditure - Investment expenditure.

Only available 1990-2011.

= Consumption expenditure - Consumption revenue. Only available 1990-2011.

= Cantonal and local consumption expenditure - Cantonal and local consumption revenue. Only available 1990-2011.

Deficit according to the income statement (Erfolgsrechnung). Includes extraordinary budget. Only available 1990-2011.

Cantonal and local deficit according to the income statement (Erfolgsrechnung). Includes extraordinary budget. Only available 1990-2011.

Depreciation of administrative assets. Only available 1990-2011.

= Investment spending / Total expenditure.

It equals one if a canton has a debt break in place in a given year and zero otherwise. See Table A.1.

It measures the stringency of cantonal debt brakes on a scale from zero (none) to three (strongest). See Feld and Kirchgässner (2001a, 2008) and Feld et al. (2013).

It equals one if a canton has an investment restriction in place in a given year and zero otherwise. See Table A.1.

Expenditure thresholds per capita for new non-recurring spending projects that trigger mandatory referenda if exceeded. It equals zero if no mandatory referenda is in place. For Fribourg (1987-1998) Jura (1980-2011) and Appenzell Outer-Rhodes (1995-2003) we used harmonized final accounting data from EFV to calculate the threshold.

Number of signatures per 1.000 inhabitants required to launch a statutory initiative process.

It equals one if mandatory referenda are in place and zero otherwise. Since 2010 the mandatory referendum in Schwyz additionally requires a parliamentary approval of less than $3 / 4$ of votes. Thus, the dummy is set to zero for the corresponding years.

Taxable income of natural persons, including special cases in $1000 \mathrm{CHF}$. Due to the transition from praenumerando taxation (tax collection on basis of the average income of the previous two years) to postnumerando taxation (tax collection according to same year's income) data had to be derived through interpolation or extrapolation in some cases.

Cantonal taxable income per capita as share of average cantonal taxable income per capita of all cantons in the sample.

Federal unconditional transfers as measured by the share in confederation receipts. For reasons of comparability data is adjusted. Mean residential population.

Share of population aged 65 and above.

Share of population aged 20 and below.

Share of population speaking German (recorded once every ten years).

Share of seats held by left-wing parties regarding fiscal matters (Green Party of Switzerland, Social Democratic Party, Swiss Party of Labor, Progressive Organizations of Switzerland, Parti socialiste autonome, Solidarity). The classification is based on publications by the Swiss Federal Statistical Office and the Federal Chancellery. As there are no official parties in Appenzell Inner-Rhodes, the share is set to zero. Year of cantonal government election.

It equals one if a canton is subject to a deficit shock (see Figure A.2) and zero otherwise. Calculation is partly based on data kindly provided by Christoph Schaltegger. Only available 1984-2011.

Data refers to the level of the cantons excluding municipalities and has been collected for all 26 cantons for every year between 1980 and 2011 unless indicated otherwise. All monetary variables are deflated to the year 2000 based on the Swiss consumer price index. Due to a revision in accounting standards, fiscal data is partly compiled from two sources of the Swiss Federal Finance Administration and has thus been adjusted. In the interest of clarity spending by category and the balance of funds and special financing are not shown. 
Table A.3 Descriptive Statistics in Total and by Institutional Regime

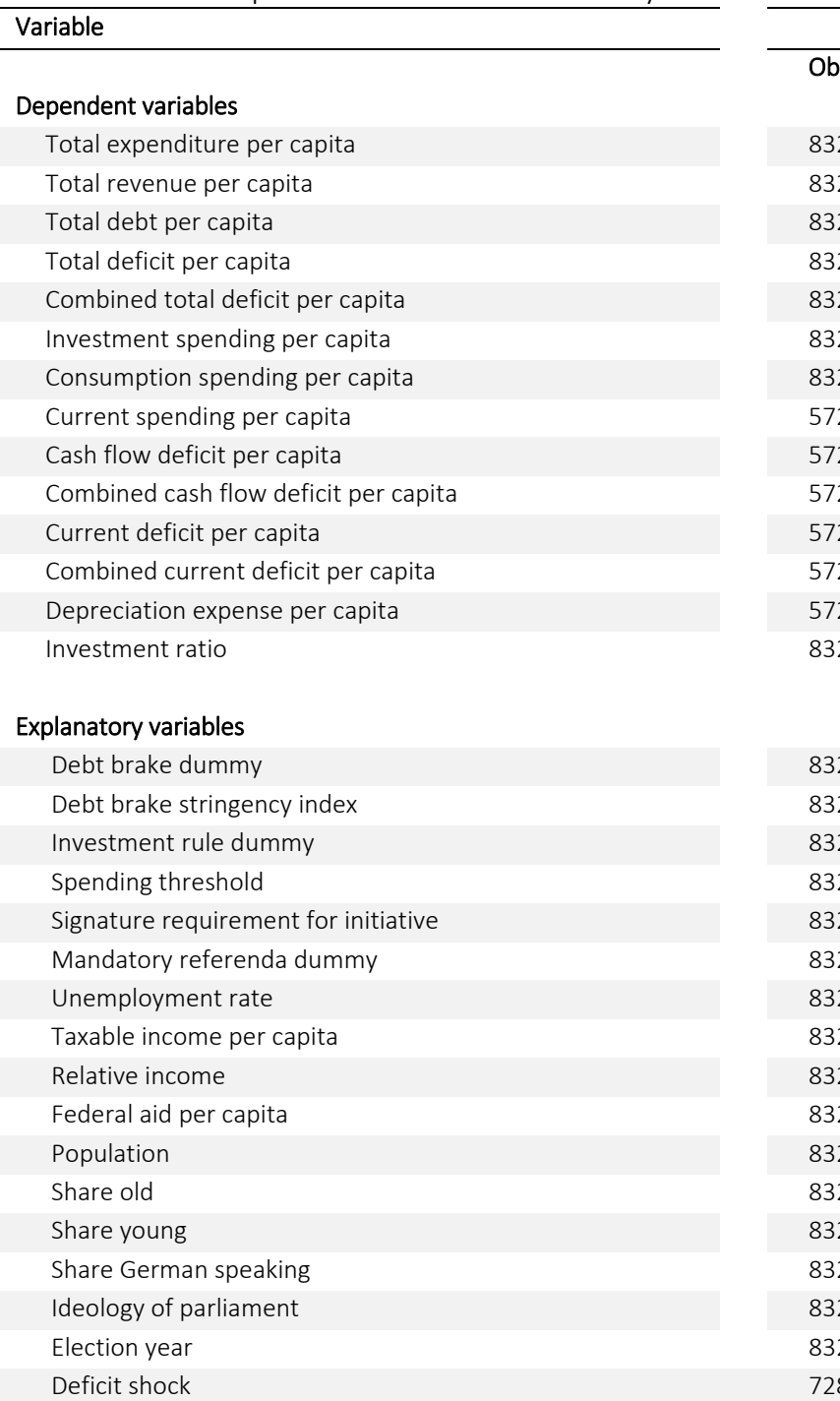

\begin{tabular}{lrrrr}
\multicolumn{5}{c}{ Total sample } \\
\hline Obs & Mean & SD & Min & Max \\
832 & 8025.203 & 3161.105 & 3814.952 & 25536.97 \\
832 & 7979.834 & 3099.921 & 3796.291 & 22955.56 \\
832 & 6724.281 & 6008.373 & 1141.057 & 50517.98 \\
832 & 45.370 & 521.878 & -2786.323 & 2978.845 \\
832 & 59.845 & 648.983 & -2778.324 & 3049.141 \\
832 & 1325.121 & 877.7533 & 198.8877 & 6192.841 \\
832 & 6700.082 & 2939.963 & 2652.417 & 24227.43 \\
572 & 8155.228 & 3066.393 & 4011.556 & 25922.73 \\
572 & -540.837 & 523.674 & -2755.555 & 1691.437 \\
572 & -1081.219 & 637.513 & -4088.694 & 1656.118 \\
572 & 17.381 & 491.518 & -1760.041 & 3359.237 \\
572 & -92.591 & 563.345 & -2205.519 & 3202.521 \\
572 & 541.145 & 352.293 & 0.000 & 3228.864 \\
832 & 0.170 & 0.090 & 0.025 & 0.616
\end{tabular}

\begin{tabular}{cc} 
Control group & \\
\hline Obs Mean
\end{tabular}

$\begin{array}{rr}607 & 8022.244 \\ 607 & 7914.066 \\ 607 & 7163.096 \\ 607 & 108.179 \\ 607 & 139.142 \\ 607 & 1428.924 \\ 607 & 6593.321 \\ 373 & 8207.294 \\ 373 & -503.266 \\ 373 & -996.039 \\ 373 & 39.837 \\ 373 & -72.839 \\ 373 & 536.323 \\ 607 & 0.183\end{array}$

\begin{tabular}{rrr}
\hline \multicolumn{3}{c}{ Treatment group $^{1}$} \\
\hline Obs & Mean & p-value $^{2}$ \\
& & \\
225 & 8033.185 & 0.965 \\
225 & 8157.26 & 0.315 \\
225 & 5540.456 & 0.001 \\
225 & -124.075 & 0.000 \\
225 & -154.082 & 0.000 \\
225 & 1045.086 & 0.000 \\
225 & 6988.099 & 0.085 \\
199 & 8057.636 & 0.579 \\
199 & -611.260 & 0.019 \\
199 & -1240.878 & 0.000 \\
199 & -24.710 & 0.135 \\
199 & -129.612 & 0.251 \\
199 & 550.183 & 0.654 \\
225 & 0.133 & 0.000
\end{tabular}

$\begin{array}{lllll}832 & 0.270 & 0.444 & 0.000 & 1.000\end{array}$

$\begin{array}{lllll}832 & 0.270 & 0.444 & 0.000 & 1.000\end{array}$

$\begin{array}{lllll}832 & 0.542 & 0.978 & 0.000 & 3.000 \\ 832 & 0.171 & 0.376 & 0.000 & 1.000\end{array}$

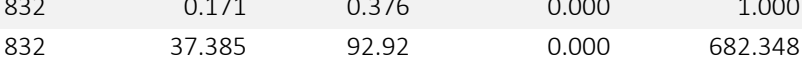

$\begin{array}{lrrrr}832 & 37.385 & 92.92 & 0.000 & 682.348 \\ 832 & 14.274 & 9.507 & 0.019 & 39.512\end{array}$

$\begin{array}{rrrrr}832 & 14.274 & 9.507 & 0.019 & 39.512 \\ 832 & 0.629 & 0.483 & 0.000 & 1.000 \\ 832 & 0.021 & 0.017 & 0.000 & 0.078\end{array}$

$\begin{array}{rrrrr}832 & 0.021 & 0.017 & 0.000 & 0.078 \\ 832 & 28.93968 & 5.746653 & 17.65365 & 53.74749\end{array}$

$\begin{array}{rrrrr}832 & 28.93968 & 5.746653 & 17.65365 & 53.74749 \\ 832 & 1.000 & 0.169 & 0.758 & 1.679\end{array}$

$\begin{array}{lllrr}832 & 630.6522 & 415.4158 & 219.6654 & 2799.572\end{array}$

$\begin{array}{rrrrr}832 & 272012.6 & 284848.7 & 12965 & 1383661 \\ 832 & 0.150 & 0.021 & 0.103 & 0.210\end{array}$

$\begin{array}{lllll}832 & 0.150 & 0.021 & 0.103 & 0.210 \\ 832 & 0.244 & 0.035 & 0.159 & 0.341 \\ 832 & 0.696 & 0.348 & 0.039 & 0.980\end{array}$

$\begin{array}{lllll}832 & 0.696 & 0.348 & 0.039 & 0.980 \\ 832 & 0.219 & 0.128 & 0.000 & 0.522\end{array}$

$\begin{array}{lllll}832 & 0.260 & 0.439 & 0.000 & 0.522 \\ 728 & 0.205 & 0.404 & 0.000 & 1.000\end{array}$

\begin{tabular}{lrrrr}
607 & 0.064 & 225 & 0.458 & 0.000 \\
607 & 39.462 & 225 & 31.780 & 0.290 \\
607 & 14.312 & 225 & 14.161 & 0.835 \\
607 & 0.595 & 225 & 0.720 & 0.001 \\
607 & 0.020 & 225 & 0.024 & 0.001 \\
607 & 28.767 & 225 & 29.405 & 0.155 \\
607 & 1.015 & 225 & 0.959 & 0.000 \\
607 & 582.205 & 225 & 761.352 & 0.000 \\
607 & 245770.1 & 225 & 342807.4 & 0.000 \\
607 & 0.149 & 225 & 0.153 & 0.044 \\
607 & 0.248 & 225 & 0.233 & 0.000 \\
607 & 0.695 & 225 & 0.701 & 0.831 \\
607 & 0.216 & 225 & 0.225 & 0.411 \\
607 & 0.264 & 225 & 0.248 & 0.668 \\
511 & 0.221 & 217 & 0.166 & 0.091 \\
\hline
\end{tabular}

In the interest of clarity spending by category and the balance of funds and special financing are not shown. 1) Cantons are recorded in the treatment group from the moment their debt brake becomes effective. 2) Twotailed $p$-value for the difference in means between the two groups of cantons. The null being that the difference between the means is zero. 


\title{
Online Appendix
}

for

\author{
EFFECTS OF FISCAL RULES
}

85 YEARS' EXPERIENCE IN SWITZERLAND

August 2016 
Online Appendix Table 1 Full Regression Body of Table 3 in the Paper: Effects of Cantonal Debt Brakes on Total Budget Variables

\begin{tabular}{|c|c|c|c|c|c|}
\hline & & & $90-2011$ & & \\
\hline & 1 & II & III & IV & $\overline{\mathrm{V}}$ \\
\hline & $\begin{array}{r}\text { Cantonal } \\
\text { expenditure }\end{array}$ & $\begin{array}{c}\text { Cantonal } \\
\text { revenue }\end{array}$ & $\begin{array}{r}\text { Cantonal } \\
\text { debt }\end{array}$ & $\begin{array}{r}\text { Cantonal } \\
\text { deficit }\end{array}$ & $\begin{array}{r}\text { Combined } \\
\text { deficit }\end{array}$ \\
\hline Debt brake & $\begin{array}{r}185.763 \\
(1.102)\end{array}$ & $\begin{array}{r}411.037^{* *} \\
(2.076)\end{array}$ & $\begin{array}{r}-1034.600^{* *} \\
(-2.322)\end{array}$ & $\begin{array}{r}-225.274^{* *} \\
(-2.664)\end{array}$ & $\begin{array}{r}-312.063^{* *} \\
(-2.746)\end{array}$ \\
\hline Signature requirement & $\begin{array}{r}-1.135 \\
(-0.056)\end{array}$ & $\begin{array}{r}-5.360 \\
(-0.251)\end{array}$ & $\begin{array}{r}183.872 * \\
(1.857)\end{array}$ & $\begin{array}{r}4.225 \\
(0.430)\end{array}$ & $\begin{array}{r}4.041 \\
(0.304)\end{array}$ \\
\hline Spending threshold & $\begin{array}{r}8.425^{* * *} \\
(9.519)\end{array}$ & $\begin{array}{r}8.820 * * * \\
(9.277)\end{array}$ & $\begin{array}{r}5.562 \\
(1.439)\end{array}$ & $\begin{array}{r}-0.395 \\
(-0.947)\end{array}$ & $\begin{array}{r}-0.483 \\
(-0.835)\end{array}$ \\
\hline Mandatory referendum & $\begin{array}{r}-292.311 \\
(-1.596)\end{array}$ & $\begin{array}{r}-317.855 \\
(-1.453)\end{array}$ & $\begin{array}{r}625.830 \\
(0.505)\end{array}$ & $\begin{array}{l}25.544 \\
(0.220)\end{array}$ & $\begin{array}{l}58.372 \\
(0.409)\end{array}$ \\
\hline Relative income & $\begin{array}{r}-8947.409 * * \\
(-2.152)\end{array}$ & $\begin{array}{r}-9232.539 * \\
(-2.050)\end{array}$ & $\begin{array}{r}-21059.568 \\
(-1.548)\end{array}$ & $\begin{array}{r}285.130 \\
(0.175)\end{array}$ & $\begin{array}{r}-856.541 \\
(-0.469)\end{array}$ \\
\hline Income & $\begin{array}{r}289.947 * * \\
(2.340)\end{array}$ & $\begin{array}{r}310.088^{* *} \\
(2.369)\end{array}$ & $\begin{array}{r}766.715 \\
(1.698)\end{array}$ & $\begin{array}{l}-20.141 \\
(-0.441)\end{array}$ & $\begin{array}{l}12.281 \\
(0.230)\end{array}$ \\
\hline Federal aid & $\begin{array}{r}0.027 \\
(0.078)\end{array}$ & $\begin{array}{r}0.511 \\
(1.326)\end{array}$ & $\begin{array}{r}1.670 \\
(1.227)\end{array}$ & $\begin{array}{r}-0.484^{* * *} \\
(-3.466)\end{array}$ & $\begin{array}{r}-0.574 * * * \\
(-3.072)\end{array}$ \\
\hline Unemployment & $\begin{array}{r}1520.826 \\
(0.167)\end{array}$ & $\begin{array}{r}-9476.017 \\
(-0.968)\end{array}$ & $\begin{array}{r}159539.634^{*} \\
(1.835)\end{array}$ & $\begin{array}{r}10996.843 * * * \\
(2.866)\end{array}$ & $\begin{array}{r}9314.397^{* *} \\
(2.081)\end{array}$ \\
\hline Population & $\begin{array}{r}-0.007^{* *} \\
(-2.436)\end{array}$ & $\begin{array}{r}-0.006 \\
(-1.416)\end{array}$ & $\begin{array}{r}0.004 \\
(0.384)\end{array}$ & $\begin{array}{r}-0.001 \\
(-0.810)\end{array}$ & $\begin{array}{r}-0.001 \\
(-0.304)\end{array}$ \\
\hline Share old & $\begin{array}{r}3456.371 \\
(0.490)\end{array}$ & $\begin{array}{r}-107.889 \\
(-0.014)\end{array}$ & $\begin{array}{r}40047.919 * \\
(2.004)\end{array}$ & $\begin{array}{r}3564.259 \\
(1.077)\end{array}$ & $\begin{array}{r}3627.857 \\
(0.930)\end{array}$ \\
\hline Share young & $\begin{array}{r}13503.032 * \\
(1.744)\end{array}$ & $\begin{array}{r}19008.841^{* *} \\
(2.123)\end{array}$ & $\begin{array}{r}110475.620^{* *} \\
(2.317)\end{array}$ & $\begin{array}{r}-5505.809 \\
(-1.416)\end{array}$ & $\begin{array}{r}-5815.617 \\
(-1.188)\end{array}$ \\
\hline Share German & $\begin{array}{r}-7635.634 \\
(-1.022)\end{array}$ & $\begin{array}{r}-7476.591 \\
(-0.913)\end{array}$ & $\begin{array}{r}5902.987 \\
(0.443)\end{array}$ & $\begin{array}{r}-159.044 \\
(-0.087)\end{array}$ & $\begin{array}{r}941.652 \\
(0.549)\end{array}$ \\
\hline Ideology & $\begin{array}{r}1114.871 \\
(0.757)\end{array}$ & $\begin{array}{r}1333.785 \\
(0.738)\end{array}$ & $\begin{array}{r}4369.545 \\
(0.609)\end{array}$ & $\begin{array}{r}-218.913 \\
(-0.347)\end{array}$ & $\begin{array}{r}-141.950 \\
(-0.182)\end{array}$ \\
\hline Two-way FE & Yes & Yes & Yes & Yes & Yes \\
\hline Adj. R2 & 0.83 & 0.84 & 0.42 & 0.33 & 0.38 \\
\hline Obs. & 832 & 832 & 832 & 832 & 832 \\
\hline Cluster & 26 & 26 & 26 & 26 & 26 \\
\hline Wald test: FE & $283^{* * *}$ & $567^{* * *}$ & $322 * * *$ & $23 * * *$ & $124 * * *$ \\
\hline
\end{tabular}


Online Appendix Table 2 Full Regression Body of Table 4 in the Paper: Effects of Cantonal Debt Brakes on Specific Budget Components

\begin{tabular}{|c|c|c|c|c|c|c|c|}
\hline & \multicolumn{5}{|c|}{$1990-2011$} & \multicolumn{2}{|c|}{$1980-2011$} \\
\hline & 1 & II & III & IV & $\mathrm{V}$ & $\mathrm{Vl}$ & $\mathrm{VII}$ \\
\hline & $\begin{array}{r}\text { Cantonal } \\
\text { current deficit }\end{array}$ & $\begin{array}{r}\text { Combined } \\
\text { current deficit }\end{array}$ & $\begin{array}{l}\text { Cantonal } \\
\text { cash flow def. }\end{array}$ & $\begin{array}{r}\text { Combined cash } \\
\text { flow def. }\end{array}$ & $\begin{array}{r}\text { Cantonal } \\
\text { depreciation }\end{array}$ & $\begin{array}{c}\text { Cantonal } \\
\text { consum. exp. }\end{array}$ & $\begin{array}{c}\text { Cantonal } \\
\text { invest. exp. }\end{array}$ \\
\hline Debt brake & $\begin{array}{r}-211.369 * \\
(-1.781)\end{array}$ & $\begin{array}{r}-307.897^{* *} \\
(-2.307)\end{array}$ & $\begin{array}{r}-283.163^{* *} \\
(-2.680)\end{array}$ & $\begin{array}{r}-428.240^{* * *} \\
(-3.506)\end{array}$ & $\begin{array}{r}107.709 * \\
(1.943)\end{array}$ & $\begin{array}{l}-68.053 \\
(-0.534)\end{array}$ & $\begin{array}{r}253.815^{* *} \\
(2.611)\end{array}$ \\
\hline $\begin{array}{l}\text { Signature } \\
\text { requirement }\end{array}$ & $\begin{array}{r}-7.885 \\
(-0.795)\end{array}$ & $\begin{array}{r}-4.474 \\
(-0.345)\end{array}$ & $\begin{array}{r}-5.015 \\
(-0.364)\end{array}$ & $\begin{array}{r}-0.144 \\
(-0.009)\end{array}$ & $\begin{array}{r}-2.873 \\
(-0.398)\end{array}$ & $\begin{array}{l}-24.591 \\
(-1.388)\end{array}$ & $\begin{array}{r}23.456 * * * \\
(3.007)\end{array}$ \\
\hline $\begin{array}{l}\text { Spending } \\
\text { threshold }\end{array}$ & $\begin{array}{r}-0.371 \\
(-0.670)\end{array}$ & $\begin{array}{r}-0.061 \\
(-0.074)\end{array}$ & $\begin{array}{l}-1.791^{*} \\
(-1.750)\end{array}$ & $\begin{array}{l}-2.062^{*} \\
(-1.906)\end{array}$ & $\begin{array}{r}0.916 \\
(1.169)\end{array}$ & $\begin{array}{r}3.082^{* * *} \\
(5.638)\end{array}$ & $\begin{array}{r}5.343 * * * \\
(9.755)\end{array}$ \\
\hline $\begin{array}{l}\text { Mandatory } \\
\text { referendum }\end{array}$ & $\begin{array}{l}-81.868 \\
(-0.514)\end{array}$ & $\begin{array}{r}-0.668 \\
(-0.003)\end{array}$ & $\begin{array}{l}-55.790 \\
(-0.335)\end{array}$ & $\begin{array}{l}73.664 \\
(0.337)\end{array}$ & $\begin{array}{l}42.707 \\
(0.586)\end{array}$ & $\begin{array}{r}-206.155 \\
(-1.113)\end{array}$ & $\begin{array}{l}-86.156 \\
(-0.844)\end{array}$ \\
\hline Relative income & $\begin{array}{r}4904.491^{*} \\
(2.017)\end{array}$ & $\begin{array}{r}6069.996 * * \\
(2.069)\end{array}$ & $\begin{array}{r}12091.835^{* * *} \\
(4.582)\end{array}$ & $\begin{array}{r}13540.392 * * * \\
(4.052)\end{array}$ & $\begin{array}{r}-4477.045^{*} \\
(-2.021)\end{array}$ & $\begin{array}{r}-6502.779 * * \\
(-2.320)\end{array}$ & $\begin{array}{r}-2444.630 \\
(-1.254)\end{array}$ \\
\hline Income & $\begin{array}{r}-154.643^{*} \\
(-1.921)\end{array}$ & $\begin{array}{r}-198.358^{* *} \\
(-2.065)\end{array}$ & $\begin{array}{r}-394.254^{* * *} \\
(-4.591)\end{array}$ & $\begin{array}{r}-436.773 * * * \\
(-4.045)\end{array}$ & $\begin{array}{r}143.125^{*} \\
(1.984)\end{array}$ & $\begin{array}{r}205.035 * * \\
(2.434)\end{array}$ & $\begin{array}{l}84.912 \\
(1.414)\end{array}$ \\
\hline Federal aid & $\begin{array}{r}-0.179 \\
(-1.529)\end{array}$ & $\begin{array}{r}-0.222 \\
(-1.649)\end{array}$ & $\begin{array}{r}-0.558 * * * \\
(-4.371)\end{array}$ & $\begin{array}{r}-0.680 * * * \\
(-4.689)\end{array}$ & $\begin{array}{r}0.113 \\
(1.397)\end{array}$ & $\begin{array}{r}0.296 \\
(1.693)\end{array}$ & $\begin{array}{r}-0.269 \\
(-1.063)\end{array}$ \\
\hline Unemployment & $\begin{array}{r}4693.307 \\
(1.683)\end{array}$ & $\begin{array}{r}7905.826^{* *} \\
(2.565)\end{array}$ & $\begin{array}{r}7625.882^{* *} \\
(2.776)\end{array}$ & $\begin{array}{r}12772.920 * * * \\
(3.914)\end{array}$ & $\begin{array}{r}-1949.798 \\
(-0.843)\end{array}$ & $\begin{array}{r}-1621.077 \\
(-0.225)\end{array}$ & $\begin{array}{r}3141.904 \\
(0.542)\end{array}$ \\
\hline Population & $\begin{array}{r}-0.000 \\
(-0.042)\end{array}$ & $\begin{array}{r}0.001 \\
(0.288)\end{array}$ & $\begin{array}{r}-0.000 \\
(-0.144)\end{array}$ & $\begin{array}{r}-0.001 \\
(-0.257)\end{array}$ & $\begin{array}{r}-0.002 \\
(-1.244)\end{array}$ & $\begin{array}{r}-0.008 * * * \\
(-3.186)\end{array}$ & $\begin{array}{r}0.000 \\
(0.143)\end{array}$ \\
\hline Share old & $\begin{array}{r}9688.867 * * \\
(2.298)\end{array}$ & $\begin{array}{r}10809.349 * \\
(1.973)\end{array}$ & $\begin{array}{r}9710.048 \\
(1.619)\end{array}$ & $\begin{array}{r}9115.744 \\
(1.182)\end{array}$ & $\begin{array}{r}-4386.698 \\
(-1.163)\end{array}$ & $\begin{array}{r}-908.025 \\
(-0.152)\end{array}$ & $\begin{array}{r}4364.396 \\
(1.016)\end{array}$ \\
\hline Share young & $\begin{array}{r}-2918.621 \\
(-0.811)\end{array}$ & $\begin{array}{r}-4453.703 \\
(-0.905)\end{array}$ & $\begin{array}{r}-5959.989 \\
(-1.488)\end{array}$ & $\begin{array}{r}-7740.436^{*} \\
(-1.774)\end{array}$ & $\begin{array}{r}5511.771 \\
(1.536)\end{array}$ & $\begin{array}{r}16609.047^{* *} \\
(2.695)\end{array}$ & $\begin{array}{r}-3106.014 \\
(-0.823)\end{array}$ \\
\hline Share German & $\begin{array}{r}-2868.842 \\
(-1.467)\end{array}$ & $\begin{array}{r}-3253.238 \\
(-1.315)\end{array}$ & $\begin{array}{r}-2208.317 \\
(-1.056)\end{array}$ & $\begin{array}{r}-3323.724 \\
(-1.169)\end{array}$ & $\begin{array}{r}-1173.139 \\
(-0.446)\end{array}$ & $\begin{array}{r}-2851.104 \\
(-0.579)\end{array}$ & $\begin{array}{r}-4784.530 \\
(-1.214)\end{array}$ \\
\hline Ideology & $\begin{array}{r}1316.053^{*} \\
(1.818)\end{array}$ & $\begin{array}{r}1880.915^{* *} \\
(2.121)\end{array}$ & $\begin{array}{l}-30.196 \\
(-0.035)\end{array}$ & $\begin{array}{r}532.073 \\
(0.551)\end{array}$ & $\begin{array}{r}912.947 \\
(1.474)\end{array}$ & $\begin{array}{r}1728.049^{*} \\
(1.877)\end{array}$ & $\begin{array}{r}-613.177 \\
(-0.640)\end{array}$ \\
\hline Two-way FE & Yes & Yes & Yes & Yes & Yes & Yes & Yes \\
\hline Adj. R2 & 0.28 & 0.27 & 0.27 & 0.32 & 0.15 & 0.91 & 0.30 \\
\hline Obs. & 572 & 572 & 572 & 572 & 572 & 832 & 832 \\
\hline Cluster & 26 & 26 & 26 & 26 & 26 & 26 & 26 \\
\hline Wald test FE & $16^{* * *}$ & $20 * * *$ & $47 * * *$ & $91^{* * *}$ & $141^{* * *}$ & $721^{* * *}$ & $889 * * *$ \\
\hline
\end{tabular}


Online Appendix Table 3 Full Regression Body of Table 5 in the Paper: Evasive Reactions to Cantonal Debt Brakes

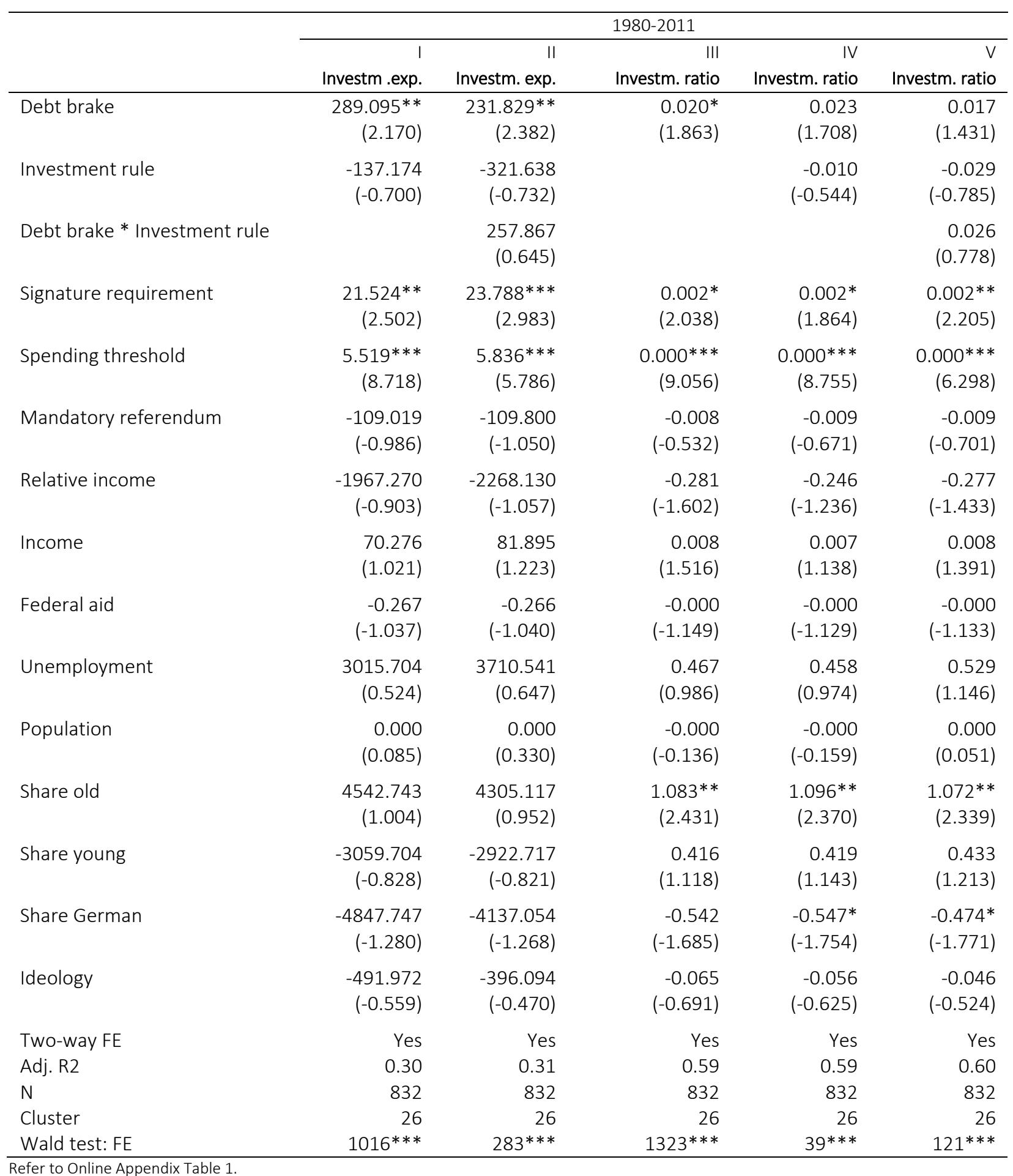


Online Appendix Table 4

Full Regression Body of Table 6 in the Paper: Political Budget Cycles and Debt Brakes

\begin{tabular}{|c|c|c|c|c|c|c|c|c|c|c|c|c|}
\hline & \multicolumn{7}{|c|}{ 1980-2011 } & \multicolumn{5}{|c|}{ 1990-2011 } \\
\hline & $\begin{array}{l}\text { Total } \\
\text { exp. }\end{array}$ & $\begin{array}{c}\text { Total } \\
\text { rev. }\end{array}$ & $\begin{array}{l}\text { Total } \\
\text { debt }\end{array}$ & $\begin{array}{r}\text { Total } \\
\text { deficit }\end{array}$ & $\begin{array}{c}\text { Combined } \\
\text { total def. }\end{array}$ & $\begin{array}{r}\text { Invest. } \\
\text { exp. }\end{array}$ & $\begin{array}{r}\text { Consum. } \\
\text { exp. }\end{array}$ & $\begin{array}{r}\text { Current } \\
\text { deficit }\end{array}$ & $\begin{array}{l}\text { Combined } \\
\text { current def. }\end{array}$ & $\begin{array}{r}\text { Cash flow } \\
\text { deficit }\end{array}$ & $\begin{array}{r}\text { Combined } \\
\text { cash flow def. }\end{array}$ & $\begin{array}{r}\text { Depreciation } \\
\text { expense }\end{array}$ \\
\hline Debt brake & $\begin{array}{r}174.857 \\
(1.052)\end{array}$ & $\begin{array}{r}398.818^{*} \\
(2.032)\end{array}$ & $\begin{array}{r}-948.850^{*} \\
(-2.014)\end{array}$ & $\begin{array}{r}-223.961^{* *} \\
(-2.694)\end{array}$ & $\begin{array}{r}-310.046^{* *} \\
(-2.708)\end{array}$ & $\begin{array}{r}250.254^{* *} \\
(2.520)\end{array}$ & \begin{tabular}{|l|}
-75.397 \\
$(-0.604)$
\end{tabular} & $\begin{array}{r}-196.587 \\
(-1.622)\end{array}$ & $\begin{array}{r}-296.880^{* *} \\
(-2.223)\end{array}$ & $\begin{array}{r}-271.878^{* *} \\
(-2.534)\end{array}$ & $\begin{array}{r}-410.292^{* * * *} \\
(-3.335)\end{array}$ & $\begin{array}{r}109.516^{*} \\
(1.925)\end{array}$ \\
\hline Election year & $\begin{array}{l}36.407 \\
(1.121)\end{array}$ & $\begin{array}{l}-43.058 \\
(-1.037)\end{array}$ & $\begin{array}{l}-72.233 \\
(-0.474)\end{array}$ & $\begin{array}{r}79.464^{* * *} \\
(3.309)\end{array}$ & $\begin{array}{r}82.212^{* * *} \\
(2.959)\end{array}$ & $\begin{array}{l}39.672 \\
(1.122)\end{array}$ & \begin{tabular}{r|}
-3.265 \\
$(-0.141)$
\end{tabular} & $\begin{array}{l}58.250 \\
(1.685)\end{array}$ & $\begin{array}{l}55.326 \\
(1.441)\end{array}$ & $\begin{array}{r}79.451^{* * *} \\
(2.851)\end{array}$ & $\begin{array}{r}94.929 * * \\
(2.702)\end{array}$ & $\begin{array}{r}5.028 \\
(0.223)\end{array}$ \\
\hline $\begin{array}{l}\text { Debt brake }{ }^{*} \\
\text { Election year }\end{array}$ & $\begin{array}{l}46.721 \\
(0.569)\end{array}$ & $\begin{array}{l}47.025 \\
(0.584)\end{array}$ & $\begin{array}{r}-353.772 \\
(-0.848)\end{array}$ & $\begin{array}{r}-0.304 \\
(-0.004)\end{array}$ & $\begin{array}{r}-2.998 \\
(-0.033)\end{array}$ & $\begin{array}{l}17.021 \\
(0.481)\end{array}$ & \begin{tabular}{l|}
29.700 \\
$(0.370)$
\end{tabular} & $\begin{array}{l}-58.240 \\
(-0.671)\end{array}$ & $\begin{array}{l}-42.552 \\
(-0.456)\end{array}$ & $\begin{array}{l}-41.962 \\
(-0.510)\end{array}$ & $\begin{array}{l}-68.985 \\
(-0.690)\end{array}$ & $\begin{array}{r}-7.268 \\
(-0.144)\end{array}$ \\
\hline $\begin{array}{l}\text { Signature } \\
\text { requirement }\end{array}$ & $\begin{array}{r}-1.275 \\
(-0.063)\end{array}$ & $\begin{array}{r}-5.436 \\
(-0.254)\end{array}$ & $\begin{array}{r}184.766^{*} \\
(1.865)\end{array}$ & $\begin{array}{r}4.161 \\
(0.422)\end{array}$ & $\begin{array}{r}3.981 \\
(0.299)\end{array}$ & $\begin{array}{r}23.384^{* * *} \\
(2.985)\end{array}$ & \begin{tabular}{l|l}
-24.659 & \\
$(-1.389)$ &
\end{tabular} & $\begin{array}{r}-7.510 \\
(-0.749)\end{array}$ & $\begin{array}{r}-4.178 \\
(-0.320)\end{array}$ & $\begin{array}{r}-4.681 \\
(-0.337)\end{array}$ & $\begin{array}{r}0.345 \\
(0.022)\end{array}$ & $\begin{array}{r}-2.830 \\
(-0.393)\end{array}$ \\
\hline $\begin{array}{l}\text { Spending } \\
\text { threshold }\end{array}$ & $\begin{array}{r}8.427 * * * \\
(9.508)\end{array}$ & $\begin{array}{r}8.824 * * * \\
(9.289)\end{array}$ & $\begin{array}{r}5.545 \\
(1.429)\end{array}$ & $\begin{array}{r}-0.398 \\
(-0.955)\end{array}$ & $\begin{array}{r}-0.486 \\
(-0.839)\end{array}$ & $\begin{array}{r}5.343 * * * \\
(9.760)\end{array}$ & \begin{tabular}{r|}
$3.084 * * *$ \\
$(5.646)$
\end{tabular} & $\begin{array}{r}-0.386 \\
(-0.704)\end{array}$ & $\begin{array}{r}-0.076 \\
(-0.092)\end{array}$ & $\begin{array}{l}-1.812^{*} \\
(-1.830)\end{array}$ & $\begin{array}{l}-2.087 * \\
(-1.987)\end{array}$ & $\begin{array}{r}0.915 \\
(1.159)\end{array}$ \\
\hline $\begin{array}{l}\text { Mandatory } \\
\text { referendum }\end{array}$ & $\begin{array}{r}-293.706 \\
(-1.579)\end{array}$ & $\begin{array}{r}-315.624 \\
(-1.446)\end{array}$ & $\begin{array}{r}627.116 \\
(0.510)\end{array}$ & $\begin{array}{l}21.917 \\
(0.188)\end{array}$ & $\begin{array}{l}54.605 \\
(0.379)\end{array}$ & $\begin{array}{l}-87.869 \\
(-0.853)\end{array}$ & $\begin{array}{r}-205.838 \\
(-1.107)\end{array}$ & $\begin{array}{l}-85.084 \\
(-0.525)\end{array}$ & $\begin{array}{r}-3.772 \\
(-0.017)\end{array}$ & $\begin{array}{l}-60.323 \\
(-0.362)\end{array}$ & $\begin{array}{l}68.321 \\
(0.309)\end{array}$ & $\begin{array}{l}42.438 \\
(0.582)\end{array}$ \\
\hline $\begin{array}{l}\text { Relative } \\
\text { income }\end{array}$ & $\begin{array}{r}-8981.410^{* *} \\
(-2.149)\end{array}$ & $\begin{array}{r}-9219.675^{*} \\
(-2.055)\end{array}$ & $\begin{array}{r}-20922.299 \\
(-1.545)\end{array}$ & $\begin{array}{r}238.264 \\
(0.148)\end{array}$ & $\begin{array}{r}-904.309 \\
(-0.498)\end{array}$ & $\begin{array}{r}-2472.619 \\
(-1.259)\end{array}$ & $\begin{array}{r}-6508.791 * * \\
(-2.321)\end{array}$ & $\begin{array}{r}4787.252^{*} \\
(1.994)\end{array}$ & $\begin{array}{r}5953.118^{*} \\
(2.047)\end{array}$ & $\begin{array}{r}11915.710^{* * *} \\
(4.509)\end{array}$ & $\begin{array}{r}13338.110 * * * \\
(3.944)\end{array}$ & $\begin{array}{r}-4486.195 * \\
(-2.012)\end{array}$ \\
\hline Income & $\begin{array}{r}290.662^{* *} \\
(2.332)\end{array}$ & $\begin{array}{r}309.709 * * \\
(2.376)\end{array}$ & $\begin{array}{r}764.102 \\
(1.695)\end{array}$ & $\begin{array}{l}-19.047 \\
(-0.420)\end{array}$ & $\begin{array}{l}13.401 \\
(0.252)\end{array}$ & $\begin{array}{l}85.537 \\
(1.413)\end{array}$ & \begin{tabular}{r|}
$205.126^{* *}$ \\
$(2.431)$
\end{tabular} & $\begin{array}{r}-150.830^{*} \\
(-1.895)\end{array}$ & $\begin{array}{r}-194.603^{*} \\
(-2.044)\end{array}$ & $\begin{array}{r}-388.662^{* * *} \\
(-4.512)\end{array}$ & $\begin{array}{r}-430.289 * * * \\
(-3.933)\end{array}$ & $\begin{array}{r}143.431^{*} \\
(1.974)\end{array}$ \\
\hline Federal aid & $\begin{array}{r}0.025 \\
(0.073)\end{array}$ & $\begin{array}{r}0.511 \\
(1.324)\end{array}$ & $\begin{array}{r}1.679 \\
(1.226)\end{array}$ & $\begin{array}{r}-0.486 * * * \\
(-3.522)\end{array}$ & $\begin{array}{r}-0.576 * * * \\
(-3.091)\end{array}$ & $\begin{array}{r}-0.270 \\
(-1.068)\end{array}$ & \begin{tabular}{r|r}
0.295 \\
$(1.686)$
\end{tabular} & $\begin{array}{r}-0.179 \\
(-1.531)\end{array}$ & $\begin{array}{r}-0.222 \\
(-1.646)\end{array}$ & $\begin{array}{r}-0.558^{* * *} \\
(-4.438)\end{array}$ & $\begin{array}{r}-0.680 * * * \\
(-4.716)\end{array}$ & $\begin{array}{r}0.113 \\
(1.391)\end{array}$ \\
\hline Unemployment & $\begin{array}{r}1524.788 \\
(0.167)\end{array}$ & $\begin{array}{r}-9488.116 \\
(-0.967)\end{array}$ & $\begin{array}{r}159550.698^{*} \\
(1.835)\end{array}$ & $\begin{array}{r}11012.904^{* * *} \\
(2.871)\end{array}$ & $\begin{array}{r}9331.208^{* *} \\
(2.092)\end{array}$ & $\begin{array}{r}3148.677 \\
(0.543)\end{array}$ & $\begin{array}{r}-1623.889 \\
(-0.225)\end{array}$ & $\begin{array}{r}4501.006 \\
(1.601)\end{array}$ & $\begin{array}{r}7711.310^{* *} \\
(2.491)\end{array}$ & $\begin{array}{r}7328.750^{* * * *} \\
(2.803)\end{array}$ & $\begin{array}{r}12435.425^{* * *} \\
(4.054)\end{array}$ & $\begin{array}{r}-1964.313 \\
(-0.847)\end{array}$ \\
\hline Population & $\begin{array}{r}-0.007 * * \\
(-2.414)\end{array}$ & $\begin{array}{r}-0.006 \\
(-1.421)\end{array}$ & $\begin{array}{r}0.004 \\
(0.383)\end{array}$ & $\begin{array}{r}-0.001 \\
(-0.818)\end{array}$ & $\begin{array}{r}-0.001 \\
(-0.301)\end{array}$ & $\begin{array}{r}0.000 \\
(0.150)\end{array}$ & $\begin{array}{r}-0.008 * * * \\
(-3.180)\end{array}$ & $\begin{array}{r}-0.000 \\
(-0.027)\end{array}$ & $\begin{array}{r}0.001 \\
(0.299)\end{array}$ & $\begin{array}{r}-0.000 \\
(-0.134)\end{array}$ & $\begin{array}{r}-0.001 \\
(-0.247)\end{array}$ & $\begin{array}{r}-0.002 \\
(-1.237)\end{array}$ \\
\hline Share old & $\begin{array}{r}3440.579 \\
(0.486)\end{array}$ & $\begin{array}{r}-187.869 \\
(-0.025)\end{array}$ & $\begin{array}{r}40331.072^{*} \\
(2.013)\end{array}$ & $\begin{array}{r}3628.448 \\
(1.103)\end{array}$ & $\begin{array}{r}3696.854 \\
(0.946)\end{array}$ & $\begin{array}{r}4379.877 \\
(1.028)\end{array}$ & \begin{tabular}{r|}
-939.298 \\
$(-0.157)$
\end{tabular} & $\begin{array}{r}9666.337^{* *} \\
(2.316)\end{array}$ & $\begin{array}{r}10762.849 * \\
(1.977)\end{array}$ & $\begin{array}{r}9605.627 \\
(1.619)\end{array}$ & $\begin{array}{r}9028.043 \\
(1.179)\end{array}$ & $\begin{array}{r}-4384.236 \\
(-1.155)\end{array}$ \\
\hline Share young & $\begin{array}{r}13389.471^{*} \\
(1.719)\end{array}$ & $\begin{array}{r}18989.227^{* *} \\
(2.111)\end{array}$ & $\begin{array}{r}111093.818^{* *} \\
(2.332)\end{array}$ & $\begin{array}{r}-5599.756 \\
(-1.465)\end{array}$ & $\begin{array}{r}-5908.775 \\
(-1.220)\end{array}$ & $\begin{array}{r}-3178.760 \\
(-0.843)\end{array}$ & $\begin{array}{r}16568.232 * * \\
(2.686)\end{array}$ & $\begin{array}{r}-2940.145 \\
(-0.805)\end{array}$ & $\begin{array}{r}-4515.493 \\
(-0.912)\end{array}$ & $\begin{array}{r}-6110.734 \\
(-1.522)\end{array}$ & $\begin{array}{r}-7859.496^{*} \\
(-1.782)\end{array}$ & $\begin{array}{r}5517.172 \\
(1.543)\end{array}$ \\
\hline Share German & $\begin{array}{r}-7643.485 \\
(-1.024)\end{array}$ & $\begin{array}{r}-7490.986 \\
(-0.915)\end{array}$ & $\begin{array}{r}5979.006 \\
(0.447)\end{array}$ & $\begin{array}{r}-152.498 \\
(-0.084)\end{array}$ & $\begin{array}{r}949.045 \\
(0.560)\end{array}$ & $\begin{array}{r}-4785.239 \\
(-1.216)\end{array}$ & $\begin{array}{r}-2858.246 \\
(-0.580)\end{array}$ & $\begin{array}{r}-2835.044 \\
(-1.453)\end{array}$ & $\begin{array}{r}-3213.779 \\
(-1.297)\end{array}$ & $\begin{array}{r}-2140.617 \\
(-1.033)\end{array}$ & $\begin{array}{r}-3253.699 \\
(-1.150)\end{array}$ & $\begin{array}{r}-1171.513 \\
(-0.443)\end{array}$ \\
\hline Ideology & $\begin{array}{r}1098.497 \\
(0.742)\end{array}$ & $\begin{array}{r}1334.882 \\
(0.736)\end{array}$ & $\begin{array}{r}4448.668 \\
(0.626)\end{array}$ & $\begin{array}{r}-236.385 \\
(-0.378)\end{array}$ & $\begin{array}{r}-159.546 \\
(-0.206)\end{array}$ & $\begin{array}{r}-624.967 \\
(-0.649)\end{array}$ & \begin{tabular}{r|r}
$1723.464 *$ & \\
$(1.863)$ &
\end{tabular} & $\begin{array}{r}1307.588^{*} \\
(1.784)\end{array}$ & $\begin{array}{r}1868.257^{* *} \\
(2.084)\end{array}$ & $\begin{array}{l}-55.300 \\
(-0.064)\end{array}$ & $\begin{array}{r}508.897 \\
(0.530)\end{array}$ & $\begin{array}{r}913.027 \\
(1.457)\end{array}$ \\
\hline Two-way FE & Yes & Yes & Yes & Yes & Yes & Yes & Yes & Yes & Yes & Yes & Yes & Yes \\
\hline Adj. R2 & 0.83 & 0.84 & 0.42 & 0.33 & 0.38 & 0.30 & 0.91 & 0.28 & 0.27 & 0.27 & 0.32 & 0.14 \\
\hline N & 832 & 832 & 832 & 832 & 832 & 832 & 832 & 572 & 572 & 572 & 572 & 572 \\
\hline Cluster & 26 & 26 & 26 & 26 & 26 & 26 & 26 & 26 & 26 & 26 & 26 & 26 \\
\hline Wald test: FE & $298^{* * *}$ & $1.163^{* * *}$ & $386^{* * *}$ & $25^{* * *}$ & $46^{* * *}$ & $1235^{* * *}$ & $1328 * * *$ & $78^{* * *}$ & $23 * * *$ & $103 * * *$ & $133 * * *$ & $88^{* * *}$ \\
\hline
\end{tabular}

Wald test: FE 
Online Appendix Table 5 Full Regression Body of Table 7 in the Paper: Fiscal Shocks and Debt Brakes

\begin{tabular}{|c|c|c|c|c|c|c|c|c|c|c|c|c|}
\hline & \multicolumn{7}{|c|}{ 1984-2011 } & \multicolumn{5}{|c|}{ 1990-2011 } \\
\hline & $\begin{array}{c}\text { Total } \\
\text { exp. }\end{array}$ & $\begin{array}{c}\text { Total } \\
\text { rev. }\end{array}$ & $\begin{array}{l}\text { Total } \\
\text { debt }\end{array}$ & $\begin{array}{r}\text { Total } \\
\text { deficit }\end{array}$ & $\begin{array}{r}\text { Combined } \\
\text { total def. }\end{array}$ & $\begin{array}{r}\text { Invest. } \\
\text { exp. }\end{array}$ & $\begin{array}{r}\begin{array}{r}\text { Consum. } \\
\text { exp. }\end{array} \\
\end{array}$ & $\begin{array}{r}\text { Current } \\
\text { deficit }\end{array}$ & $\begin{array}{l}\text { Combined } \\
\text { current def. }\end{array}$ & Cash flow deficit & $\begin{array}{r}\text { Combined } \\
\text { cash flow def. }\end{array}$ & $\begin{array}{r}\text { Depreciation } \\
\text { expense }\end{array}$ \\
\hline Debt brake & $\begin{array}{r}198.806 \\
(1.131)\end{array}$ & $\begin{array}{r}424.044^{*} \\
(2.052)\end{array}$ & $\begin{array}{r}-992.605^{* *} \\
(-2.219)\end{array}$ & $\begin{array}{r}-225.237^{* *} \\
(-2.468)\end{array}$ & $\begin{array}{r}-328.295^{* *} \\
(-2.704)\end{array}$ & $\begin{array}{r}206.039^{*} \\
(1.902)\end{array}$ & $\begin{array}{r}-7.232 \\
(-0.060)\end{array}$ & $\begin{array}{r}-230.949 * * \\
(-2.349)\end{array}$ & $\begin{array}{r}-323.501^{* * *} \\
(-2.949)\end{array}$ & $\begin{array}{r}-261.929 * * \\
(-2.564)\end{array}$ & $\begin{array}{r}-390.085^{* * *} \\
(-3.263)\end{array}$ & $\begin{array}{l}84.366 \\
(1.539)\end{array}$ \\
\hline Deficit shock & $\begin{array}{r}100.477 \\
(1.540)\end{array}$ & $\begin{array}{r}-119.444^{* *} \\
(-2.086)\end{array}$ & $\begin{array}{r}-168.446 \\
(-0.949)\end{array}$ & $\begin{array}{r}219.922^{* * *} \\
(5.281)\end{array}$ & $\begin{array}{r}313.366^{* * *} \\
(6.621)\end{array}$ & $\begin{array}{r}-7.237 \\
(-0.174)\end{array}$ & $\begin{array}{r}107.714^{*} \\
(1.921)\end{array}$ & $\begin{array}{r}309.501^{* * *} \\
(5.420)\end{array}$ & $\begin{array}{r}400.460^{* * *} \\
(6.235)\end{array}$ & $\begin{array}{r}259.995^{* * *} \\
(7.485)\end{array}$ & $\begin{array}{r}331.171^{* * *} \\
(7.939)\end{array}$ & $\begin{array}{l}13.396 \\
(0.507)\end{array}$ \\
\hline Debt brake * Deficit shock & $\begin{array}{l}-66.326 \\
(-0.596)\end{array}$ & $\begin{array}{l}25.915 \\
(0.160)\end{array}$ & $\begin{array}{r}-195.303 \\
(-0.542)\end{array}$ & $\begin{array}{l}-92.241 \\
(-0.665)\end{array}$ & $\begin{array}{l}-79.687 \\
(-0.603)\end{array}$ & $\begin{array}{l}25.812 \\
(0.284)\end{array}$ & $\begin{array}{l}-92.138 \\
(-0.985)\end{array}$ & $\begin{array}{l}99.127 \\
(1.047)\end{array}$ & $\begin{array}{l}86.804 \\
(0.722)\end{array}$ & $\begin{array}{l}-77.252 \\
(-1.208)\end{array}$ & $\begin{array}{r}-145.714^{*} \\
(-1.932)\end{array}$ & $\begin{array}{r}100.119 \\
(1.543)\end{array}$ \\
\hline Signature requirement & $\begin{array}{r}1.093 \\
(0.059)\end{array}$ & $\begin{array}{r}-3.611 \\
(-0.172)\end{array}$ & $\begin{array}{r}182.328^{*} \\
(1.919)\end{array}$ & $\begin{array}{r}4.704 \\
(0.457)\end{array}$ & $\begin{array}{r}4.028 \\
(0.295)\end{array}$ & $\begin{array}{r}27.702^{* * *} \\
(3.928)\end{array}$ & $\begin{array}{l}-26.609 \\
(-1.690)\end{array}$ & $\begin{array}{r}-7.866 \\
(-1.037)\end{array}$ & $\begin{array}{r}-4.314 \\
(-0.421)\end{array}$ & $\begin{array}{r}-4.473 \\
(-0.361)\end{array}$ & $\begin{array}{r}0.701 \\
(0.050)\end{array}$ & $\begin{array}{r}-3.186 \\
(-0.433)\end{array}$ \\
\hline Spending threshold & $\begin{array}{r}7.142 * * * \\
(8.775)\end{array}$ & $\begin{array}{r}8.266^{* * *} \\
(8.091)\end{array}$ & $\begin{array}{r}5.425 \\
(1.406)\end{array}$ & $\begin{array}{r}-1.124^{* *} \\
(-2.252)\end{array}$ & $\begin{array}{r}-1.575^{* *} \\
(-2.405)\end{array}$ & $\begin{array}{r}3.982 * * * \\
(8.882)\end{array}$ & $\begin{array}{r}3.161^{* * *} \\
(5.669)\end{array}$ & $\begin{array}{r}-0.590 \\
(-1.133)\end{array}$ & $\begin{array}{r}-0.348 \\
(-0.446)\end{array}$ & $\begin{array}{l}-1.990^{*} \\
(-2.045)\end{array}$ & $\begin{array}{r}-2.320^{* *} \\
(-2.282)\end{array}$ & $\begin{array}{r}0.916 \\
(1.193)\end{array}$ \\
\hline Mandatory referendum & $\begin{array}{r}-114.707 \\
(-0.784)\end{array}$ & $\begin{array}{r}-183.839 \\
(-1.000)\end{array}$ & $\begin{array}{r}739.207 \\
(0.650)\end{array}$ & $\begin{array}{l}69.132 \\
(0.657)\end{array}$ & $\begin{array}{l}99.802 \\
(0.746)\end{array}$ & $\begin{array}{l}91.905 \\
(1.194)\end{array}$ & $\begin{array}{r}-206.612 \\
(-1.333)\end{array}$ & $\begin{array}{l}-60.696 \\
(-0.494)\end{array}$ & $\begin{array}{l}23.637 \\
(0.123)\end{array}$ & $\begin{array}{l}-49.965 \\
(-0.346)\end{array}$ & $\begin{array}{l}77.558 \\
(0.394)\end{array}$ & $\begin{array}{l}50.763 \\
(0.694)\end{array}$ \\
\hline Relative income & $\begin{array}{r}-10266.309 * \\
(-2.045)\end{array}$ & $\begin{array}{r}-12823.400^{* *} \\
(-2.582)\end{array}$ & $\begin{array}{r}-26200.948 \\
(-1.373)\end{array}$ & $\begin{array}{r}2557.091 \\
(1.674)\end{array}$ & $\begin{array}{r}1397.956 \\
(0.827)\end{array}$ & $\begin{array}{r}-1936.757 \\
(-0.855)\end{array}$ & $\begin{array}{r}-8329.552^{* *} \\
(-2.629)\end{array}$ & $\begin{array}{r}4636.027^{* *} \\
(2.170)\end{array}$ & $\begin{array}{r}5803.320^{* *} \\
(2.202)\end{array}$ & $\begin{array}{r}12178.757^{* * *} \\
(5.195)\end{array}$ & $\begin{array}{r}13743.199 * * * \\
(4.579)\end{array}$ & $\begin{array}{r}-4675.187^{*} \\
(-2.058)\end{array}$ \\
\hline Income & $\begin{array}{r}341.857^{* *} \\
(2.354)\end{array}$ & $\begin{array}{r}443.096^{* * * *} \\
(3.077)\end{array}$ & $\begin{array}{r}884.232 \\
(1.422)\end{array}$ & $\begin{array}{r}-101.239 * * \\
(-2.218)\end{array}$ & $\begin{array}{l}-68.764 \\
(-1.291)\end{array}$ & $\begin{array}{l}78.169 \\
(1.190)\end{array}$ & $\begin{array}{r}263.688^{* * *} \\
(2.864)\end{array}$ & $\begin{array}{r}-149.515^{* *} \\
(-2.079)\end{array}$ & $\begin{array}{r}-194.245^{* *} \\
(-2.245)\end{array}$ & $\begin{array}{r}-399.714^{* * *} \\
(-5.232)\end{array}$ & $\begin{array}{r}-446.606^{* * *} \\
(-4.628)\end{array}$ & $\begin{array}{r}149.178^{*} \\
(2.020)\end{array}$ \\
\hline Federal aid & $\begin{array}{r}-0.110 \\
(-0.345)\end{array}$ & $\begin{array}{r}0.414 \\
(1.128)\end{array}$ & $\begin{array}{r}1.431 \\
(1.115)\end{array}$ & $\begin{array}{r}-0.524 * * * \\
(-3.711)\end{array}$ & $\begin{array}{r}-0.614^{* * *} \\
(-3.290)\end{array}$ & $\begin{array}{r}-0.346 \\
(-1.433)\end{array}$ & $\begin{array}{r}0.236 \\
(1.500)\end{array}$ & $\begin{array}{r}-0.172 \\
(-1.495)\end{array}$ & $\begin{array}{r}-0.214 \\
(-1.576)\end{array}$ & $\begin{array}{r}-0.557^{* * *} \\
(-4.387)\end{array}$ & $\begin{array}{r}-0.681^{* * *} \\
(-4.698)\end{array}$ & $\begin{array}{r}0.116 \\
(1.433)\end{array}$ \\
\hline Unemployment & $\begin{array}{r}-4117.656 \\
(-0.507)\end{array}$ & $\begin{array}{r}-15290.744 \\
(-1.641)\end{array}$ & $\begin{array}{r}152031.004^{*} \\
(1.837)\end{array}$ & $\begin{array}{r}11173.087^{* * *} \\
(3.269)\end{array}$ & $\begin{array}{r}9400.046^{* *} \\
(2.329)\end{array}$ & $\begin{array}{l}55.078 \\
(0.011)\end{array}$ & $\begin{array}{r}-4172.734 \\
(-0.700)\end{array}$ & $\begin{array}{r}4408.060 \\
(1.559)\end{array}$ & $\begin{array}{r}7544.026^{* *} \\
(2.323)\end{array}$ & $\begin{array}{r}7414.446^{* *} \\
(2.491)\end{array}$ & $\begin{array}{r}12511.908^{* * *} \\
(3.437)\end{array}$ & $\begin{array}{r}-1978.970 \\
(-0.864)\end{array}$ \\
\hline Population & $\begin{array}{r}-0.007 * * \\
(-2.122)\end{array}$ & $\begin{array}{r}-0.005 \\
(-1.337)\end{array}$ & $\begin{array}{r}0.001 \\
(0.079)\end{array}$ & $\begin{array}{r}-0.001 \\
(-0.768)\end{array}$ & $\begin{array}{r}-0.001 \\
(-0.271)\end{array}$ & $\begin{array}{r}0.001 \\
(1.205)\end{array}$ & $\begin{array}{r}-0.008^{* * *} \\
(-3.244)\end{array}$ & $\begin{array}{r}0.000 \\
(0.018)\end{array}$ & $\begin{array}{r}0.001 \\
(0.389)\end{array}$ & $\begin{array}{r}-0.000 \\
(-0.153)\end{array}$ & $\begin{array}{r}-0.001 \\
(-0.281)\end{array}$ & $\begin{array}{r}-0.002 \\
(-1.184)\end{array}$ \\
\hline Share old & $\begin{array}{r}600.820 \\
(0.090)\end{array}$ & $\begin{array}{r}-6600.668 \\
(-0.907)\end{array}$ & $\begin{array}{r}45781.832^{*} \\
(2.032)\end{array}$ & $\begin{array}{r}7201.488^{*} \\
(2.033)\end{array}$ & $\begin{array}{r}6637.912 \\
(1.516)\end{array}$ & $\begin{array}{r}4131.531 \\
(1.146)\end{array}$ & $\begin{array}{r}-3530.711 \\
(-0.673)\end{array}$ & $\begin{array}{r}6714.177^{*} \\
(1.795)\end{array}$ & $\begin{array}{r}7229.666 \\
(1.370)\end{array}$ & $\begin{array}{r}8253.724 \\
(1.445)\end{array}$ & $\begin{array}{r}7568.020 \\
(1.032)\end{array}$ & $\begin{array}{r}-5137.829 \\
(-1.401)\end{array}$ \\
\hline Share young & $\begin{array}{r}9888.260 \\
(1.242)\end{array}$ & $\begin{array}{r}16369.147^{*} \\
(1.780)\end{array}$ & $\begin{array}{r}110126.934^{* *} \\
(2.214)\end{array}$ & $\begin{array}{r}-6480.887 * \\
(-1.910)\end{array}$ & $\begin{array}{r}-7505.079 * \\
(-1.717)\end{array}$ & $\begin{array}{r}-6388.240 * \\
(-1.727)\end{array}$ & $\begin{array}{r}16276.499 * * \\
(2.461)\end{array}$ & $\begin{array}{r}-3464.274 \\
(-1.164)\end{array}$ & $\begin{array}{r}-5057.066 \\
(-1.250)\end{array}$ & $\begin{array}{r}-6020.870 \\
(-1.698)\end{array}$ & $\begin{array}{r}-7700.825^{*} \\
(-1.949)\end{array}$ & $\begin{array}{r}5250.859 \\
(1.435)\end{array}$ \\
\hline Share German & $\begin{array}{r}-5599.652 \\
(-0.830)\end{array}$ & $\begin{array}{r}-5392.209 \\
(-0.700)\end{array}$ & $\begin{array}{r}15308.842 \\
(0.920)\end{array}$ & $\begin{array}{r}-207.443 \\
(-0.112)\end{array}$ & $\begin{array}{r}1120.337 \\
(0.636)\end{array}$ & $\begin{array}{r}-4482.440 \\
(-1.257)\end{array}$ & $\begin{array}{r}-1117.213 \\
(-0.244)\end{array}$ & $\begin{array}{r}-2247.987 \\
(-1.258)\end{array}$ & $\begin{array}{r}-2506.473 \\
(-1.082)\end{array}$ & $\begin{array}{r}-1905.757 \\
(-0.939)\end{array}$ & $\begin{array}{r}-3002.880 \\
(-1.057)\end{array}$ & $\begin{array}{r}-1015.537 \\
(-0.385)\end{array}$ \\
\hline Ideology & $\begin{array}{r}1193.717 \\
(0.683)\end{array}$ & $\begin{array}{r}1874.198 \\
(0.921)\end{array}$ & $\begin{array}{r}-143.730 \\
(-0.018)\end{array}$ & $\begin{array}{r}-680.481 \\
(-1.198)\end{array}$ & $\begin{array}{r}-701.056 \\
(-0.959)\end{array}$ & $\begin{array}{r}-221.757 \\
(-0.202)\end{array}$ & $\begin{array}{r}1415.474 \\
(1.412)\end{array}$ & $\begin{array}{r}1023.839 * \\
(1.720)\end{array}$ & $\begin{array}{r}1511.901^{* *} \\
(2.106)\end{array}$ & $\begin{array}{r}-240.516 \\
(-0.292)\end{array}$ & $\begin{array}{r}274.537 \\
(0.298)\end{array}$ & $\begin{array}{r}879.314 \\
(1.351)\end{array}$ \\
\hline Controls & Ye & Yes & Yes & Yes & Yes & Yes & Yes & Yes & Yes & Yes & Yes & Yes \\
\hline Adj. R2 & 0.81 & 0.82 & 0.39 & 0.38 & 0.44 & 0.34 & 0.89 & 0.37 & 0.37 & 0.31 & 0.36 & 0.15 \\
\hline $\mathrm{N}$ & 728 & 728 & 728 & 728 & 728 & 728 & 728 & 572 & 572 & 572 & 572 & 572 \\
\hline Cluster & 26 & 26 & 26 & 26 & 26 & 26 & 26 & 26 & 26 & 26 & 26 & 26 \\
\hline Wald test: FE & $867 * * *$ & $770^{* * *}$ & $248^{* * *}$ & $27^{* * *}$ & $33^{* * *}$ & $450 * * *$ & $1788^{* * *}$ & $14^{* * *}$ & $57^{* * *}$ & $55^{* * *}$ & $17^{* * *}$ & $215^{* * * *}$ \\
\hline
\end{tabular}

Refer to Online Appendix Table 1. 